\title{
The role of eastern Tethys seaway closure in the Middle Miocene Climatic Transition (ca. 14 Ma)
}

\author{
N. Hamon ${ }^{1,2}$, P. Sepulchre ${ }^{2}$, V. Lefebvre ${ }^{3,2}$, and G. Ramstein ${ }^{2}$ \\ ${ }^{1}$ Institut de Paléoprimatologie, Paléontologie Humaine: Evolution et Paléoenvironnements, UMR7262, \\ CNRS-INEE-Université de Poitiers, Poitiers, France \\ ${ }^{2}$ Laboratoire des Sciences du Climat et de l'Environnement, UMR8212, CEA-CNRS-Université de Versailles \\ Saint-Quentin-en-Yvelines, Gif-sur-Yvette, France \\ ${ }^{3}$ Géosciences Environnement Toulouse, UMR5563, CNRS-UPS-IRD-CNES, Toulouse, France
}

Correspondence to: N. Hamon (noemiehamon@yahoo.fr)

Received: 15 March 2013 - Published in Clim. Past Discuss.: 15 April 2013

Revised: 10 October 2013 - Accepted: 28 October 2013 - Published: 28 November 2013

\begin{abstract}
The Middle Miocene Climatic Transition (MMCT, approximately $14 \mathrm{Ma}$ ) is a key period in Cenozoic cooling and cryospheric expansion. Despite being well documented in isotopic record, the causes of the MMCT are still a matter of debate. Among various hypotheses, some authors suggested that it was due the final closure of the eastern Tethys seaway and subsequent oceanic circulation reorganisation. The aim of the present study is to quantify the impact of varying Tethys seaway depths on middle Miocene ocean and climate, in order to better understand its role in the MMCT.

We present four sensitivity experiments with a fully coupled ocean-atmosphere general circulation model. Our results indicate the presence of a warm and salty water source in the northern Indian Ocean when the eastern Tethys is deep open $(4000$ or $1000 \mathrm{~m})$, which corresponds to the Tethyan Indian Saline Water (TISW) described on the basis of isotopic studies. This water source is absent in the experiments with shallow $(250 \mathrm{~m})$ and closed Tethys seaway, inducing strong changes in the latitudinal density gradient and ultimately the reinforcement of the Antarctic Circumpolar Current (ACC). Moreover, when the Tethys seaway is shallow or closed, there is a westward water flow in the Gibraltar Strait that strengthens the Atlantic Meridional Overturning Circulation (AMOC) compared to the experiments with deep-open Tethys seaway. Our results therefore suggest that the shoaling and final closure of the eastern Tethys seaway played a major role in the oceanic circulation reorganisation during the middle Miocene.
\end{abstract}

The results presented here provide new constraints on the timing of the Tethys seaway closure and particularly indicate that, prior to $14 \mathrm{Ma}$, a deep-open Tethys seaway should have allowed the formation of TISW. Moreover, whereas the final closure of this seaway likely played a major role in the reorganisation of oceanic circulation, we suggest that it was not the main driver of the global cooling and Antarctica ice-sheet expansion during the MMCT. Here we propose that the initiation of the MMCT was caused by an atmospheric $p \mathrm{CO}_{2}$ drawdown and that the oceanic changes due to the Tethys seaway closure amplified the response of global climate and East Antarctic Ice Sheet.

\section{Introduction}

The Miocene was a period of major climatic and oceanographic changes (Zachos et al., 2001). In particular, the Middle Miocene Climatic Transition (MMCT), approximately 14.2 to $13.8 \mathrm{Ma}$, was a major step in the Cenozoic global cooling and Antarctic ice-sheet expansion (Zachos et al., 2001; Billups and Schrag, 2002; Shevenell et al., 2004). This period is marked in marine carbonates $\delta^{18} \mathrm{O}$, by a twostep increase of approximately $1 \%$, which is interpreted as the consequence of a global cooling of approximately $3{ }^{\circ} \mathrm{C}$ in the deep ocean (Billups and Schrag, 2002), as well as the expansion of the East Antarctic Ice Sheet (Woodruff and Savin, 1989; Flower and Kennett, 1994; Zachos et al., 2001; Billups and Schrag, 2002; Shevenell et al., 2004). 
A major reorganisation of oceanic circulation was also inferred from oceanic data (Flower and Kennett, 1994; Pagani et al., 1999; Shevenell et al., 2004; Holbourn et al., 2013). The proto-Antarctic Circumpolar Current (ACC) was notably reinforced, and the southern frontal system moved northwards during the middle Miocene (Pagani et al., 1999; Shevenell et al., 2004; Kuhnert et al., 2009; Verducci et al., 2009). Oceanic data also suggest a reinforcement of the Atlantic meridional overturning circulation during the middle Miocene (Woodruff and Savin, 1989; Wright et al., 1992).

Although it is well documented in both continental and oceanic data (Zachos et al., 2001; Billups and Schrag, 2002; Shevenell et al., 2004, 2008; Mosbrugger et al., 2005; Bruch et al., 2007; Utescher et al., 2011), the causes of the MMCT are still highly debated. Some authors argue that it was due to an atmospheric $\mathrm{CO}_{2}$ concentration drawdown (Shevenell et al., 2004; Holbourn et al., 2005; Tripati et al., 2009; Foster et al., 2012; Badger et al., 2013), but $p \mathrm{CO}_{2}$ variations during the Miocene are not well constrained (Cerling, 1991; Pagani et al., 1999, 2009; Pearson and Palmer, 2000; Royer et al., 2001; Kürschner et al., 2008; Kürschner and Kvacek, 2009; Tripati et al., 2009). Indeed the reconstructions for the Middle Miocene Climatic Optimum (MMCO, approximately $17-15 \mathrm{Ma}$ ) are highly controversial, varying from 200 to $700 \mathrm{ppmv}$, whereas the majority of published studies agree that the atmospheric $p \mathrm{CO}_{2}$ was low (approximately 200300 ppmv) during the MMCT (Cerling, 1991; Pagani et al., 1999, 2009; Pearson and Palmer, 2000; Royer et al., 2001; Kürschner et al., 2008; Kürschner and Kvacek, 2009; Tripati et al., 2009; Foster et al., 2012; Badger et al., 2013). Insolation has also been proposed as the driver of the East Antarctic Ice Sheet expansion (Shevenell et al., 2004, 2008; Holbourn et al., 2005, 2013), and modelling studies suggested that, at low atmospheric $\mathrm{CO}_{2}$ concentration, orbital configuration is a major driver of ice-sheet development (DeConto et al., 2007). Therefore the atmospheric $\mathrm{CO}_{2}$ concentration decline could have been either the initial cause of the East Antarctic Ice Sheet growth or a positive feedback of cooling during the MMCT (Holbourn et al., 2005, 2013; Badger et al., 2013).

Geographic changes have also been invoked to explain the Middle Miocene Climatic Transition. In particular, some authors suggested that it was initiated by the final closure of the eastern Tethys seaway, and the end of water exchanges between the Indian Ocean and the proto-Mediterranean Basin (Woodruff and Savin, 1989; Wright et al., 1992; Flower and Kennett, 1994, 1995; Ramsay et al., 1998). However, the timing of the Tethys seaway closure and its consequences for oceanic circulation and climate are still poorly constrained.

During the Cenozoic, the collision between the AfroArabian and Eurasian plates closed the Tethys seaway which connected the proto-Mediterranean Basin and the Indian Ocean (Rögl, 1999; Harzhauser and Piller, 2007; Harzhauser et al., 2007, 2009). The timing of this seaway closure is still under debate. Based on the study of deformation and uplift during the collision between the two tectonic plates, Allen and Armstrong (2008) suggest a late Eocene age for the closure of the eastern Tethys seaway. However, on the basis of the stratigraphic record in the Zagros Basin, Okay et al. (2010) deduce that the collision between Afro-Arabia and Eurasia occurred in the early Miocene, approximately $19 \mathrm{Ma}$. This estimated age for the closure the Tethys seaway is consistent with the first evidence of mammal exchanges between the two continents, the so-called Gomphotherium landbridge (Rögl, 1999; Harzhauser and Piller, 2007; Harzhauser et al., 2007). Finally, stratigraphic and oceanic palaeontological data indicate that the Mediterranean Basin and the Indian Ocean were intermittently connected until at least the middle Miocene (Rögl, 1999; Harzhauser and Piller, 2007; Harzhauser et al., 2007, 2009; Okay et al., 2010). The consensual view is that, after the initial collision between AfroArabia and Eurasia, the remaining eastern Tethys seaway was not floored by oceanic crust, and the re-opening phases were mainly due to sea-level changes (Rögl, 1999; Harzhauser and Piller, 2007; Harzhauser et al., 2007, 2009; Allen and Armstrong, 2008; Hüsing et al., 2009; Reuter et al., 2009; Okay et al., 2010). The final closure of the Tethys seaway after the Langhian transgression (ca. 16-14 Ma) ended the water exchanges between the proto-Mediterranean Sea and the Indian Ocean, and coincides with the beginning of the MMCT (Rögl, 1999; Harzhauser and Piller, 2007; Zachos et al., 2001; Shevenell et al., 2004).

Inferences from marine isotopic data suggest the existence, prior to $14 \mathrm{Ma}$, of a warm and saline water mass, the so-called Tethyan Indian Saline Water (hereafter TISW), that transported heat from the Northern Indian Ocean to the Southern Ocean (Woodruff and Savin, 1989; Wright et al., 1992; Flower and Kennett, 1994, 1995; Ramsay et al., 1998). The presence of this warm water in the Southern Ocean should have been associated with a slow proto-ACC, preventing the East Antarctic Ice Sheet growth during the early and early middle Miocene (Woodruff and Savin, 1989; Wright et al., 1992). Around $14 \mathrm{Ma}$, the final closure of the eastern Tethys seaway would have terminated the formation of the TISW. Ultimately, this should have allowed ice-sheet expansion through three hypothesised mechanisms: (i) decrease in southward heat transport (Woodruff and Savin, 1989; Flower and Kennett, 1994, 1995), (ii) acceleration of the protoACC (Flower and Kennett, 1995; Kuhnert et al., 2009; Verducci et al., 2009) and (iii) enhancement of North Atlantic Deep Water production and meridional heat transport, driving an increase in evaporation over the ocean and ultimately more precipitation over Antarctica (Wright et al., 1992). Interestingly, hypotheses (i) and (iii) are contradictory: the first one suggests that increased heat transport prevented the East Antarctic Ice Sheet growth, whereas the second one argues that increased heat transport should have favoured the ice-sheet building by increasing precipitation. Therefore the possible role of the eastern Tethys seaway closure in the MMCT is not yet fully understood. Moreover, a recent 
study challenged the existence of TISW in the western Indian Ocean between approximately 17 and $5 \mathrm{Ma}$ (Smart et al., 2007). A detailed modelling study using a coupled oceanatmosphere generalised circulation model (GCM) should bring important elements on the formation of TISW during the MMCT and on the impact of the eastern Tethys seaway closure on the oceanic circulation and climate.

During the last few years, many modelling studies focused on the middle Miocene climate. Most of them investigated the impact of varying $p \mathrm{CO}_{2}$ on middle Miocene climate, and concluded that high $p \mathrm{CO}_{2}$ is necessary to simulate climatic conditions consistent with data-based reconstructions (Tong et al., 2009; You et al., 2009; Henrot et al., 2010; Krapp and Jungclaus, 2011; Hamon et al., 2012). Henrot et al. (2010) and Herold et al. (2009) also performed sensitivity experiments on palaeogeography, but they did not study the impact of the eastern Tethys seaway closure. von der Heydt and Dijkstra $(2005,2006)$ studied the impact of this event on Caribbean oceanic circulation and temperatures. Using the coupled GCM CCSM1.4 with an idealised flat-bottom ocean $(5000 \mathrm{~m})$, they suggested that the closure of the Tethys seaway and the opening of the Drake Passage induced a reversal of water transport in the Panama seaway, provoking a local cooling in this region. However, the geographic configurations used in these studies correspond to the late Oligocene (open seaway) and the early Miocene (closed seaway), which do not allow a conclusion on the effect of eastern Tethys seaway closure on global climate and ocean during the middle Miocene (von der Heydt and Dijkstra, 2005, 2006). Using the coupled GCM FOAMv1.5 (Fast Ocean Atmosphere Model version 1.5), Zhang et al. (2011) showed that the closure of the eastern Tethys and Panama seaways were key in the development of a modern-like oceanic circulation dominated by the North Atlantic Deep Water (NADW). Their results also show that the constriction of tropical seaways drives a drop of sea surface temperatures and surface salinity in the Indian Ocean (Zhang et al., 2011), but they cannot be used to precisely discuss the role of the Tethys seaway closure in the MMCT, the closure of the two gateways (Panama and eastern Tethys) being tested in the same experiment.

More recently, some studies focused precisely on the impact of the eastern Tethys seaway closure. Using an ocean circulation carbon cycle model of intermediate complexity, Butzin et al. (2011) tested the effect of various seaways configurations on ocean circulation during the Miocene. Their results indicate that the closure of the Tethys seaway leads to a cooling of up to $4{ }^{\circ} \mathrm{C}$ between 500 and $2000 \mathrm{~m}$ in the Indian Ocean. Although this result can be interpreted as the consequence of the termination of TISW production, Butzin et al. (2011) did not unequivocally diagnose this water mass in their model experiments. Using an oceanic three-box model (boxes corresponding to the Atlantic Ocean, the Indian Ocean and the Mediterranean-Paratethys Basin), Karami et al. (2009) investigated the effect of Tethys seaway closure. Their results particularly indicate a west-to-east flow (from the Atlantic Ocean to the Indian Ocean through the Mediterranean-Paratethys Basin) prior to the closure, which could have been the source of TISW in the Indian Ocean (Karami et al., 2009). In a more detailed study (2 different boxes for the Mediterranean and the Paratethys basins), Karami et al. (2011) focused on the salinity, water exchanges and temperature changes induced by the Tethys seaway closure. In their study, the closure of the Tethys gateway caused a cooling and a salinity change in the Paratethys, which became more responsive to climate changes (Karami et al., 2011). These box model studies highlight the possibly important role of the Tethys seaway closure in the Middle Miocene Climatic Transition, but modelling experiments using a fully coupled ocean-atmosphere GCM are necessary to better constrain the impact of the eastern Tethys seaway on global oceanic circulation and climate.

In the present study, we perform the first sensitivity experiments on the depth of the eastern Tethys seaway using a fully coupled ocean-atmosphere generalised circulation model (OAGCM). We particularly focus on the identification of TISW, and on the impact of closure on the global oceanic circulation. We also test the three hypotheses concerning the way the closure affected the East Antarctic Ice Sheet expansion, and finally discuss the possible role of the eastern Tethys seaway closure in the MMCT.

\section{Model and experiment design}

FOAM version 1.5 is a fully coupled OAGCM (Tobis et al., 1997). The atmospheric component is a parallelised version of Community Climate Model 2 (CCM2) developed at the National Center for Atmospheric Research (NCAR), with atmospheric physics upgraded following CCM3 (Tobis et al., 1997). Compared to CCM2, the soil hydrology module of FOAMv1.5 is replaced by a simple bucket model ( $0.15 \mathrm{~m}$ deep). When overflow from the bucket occurs, it is routed to the ocean using a parallel river transport. The direction of the transport is prescribed as a boundary condition. The atmospheric component runs at R15 $\left(4.5^{\circ} \times 7.5^{\circ}\right)$ spatial resolution, with 18 vertical layers. The oceanic component is a parallel ocean model dynamically similar to the Geophysical Fluid Dynamics Laboratory's Modular Ocean Model (MOM) (Tobis et al., 1997). The spatial resolution of the oceanic component is a $128 \times 128$ Mercator grid $\left(1.4^{\circ} \times 2.8^{\circ}\right)$, with 24 vertical levels. The atmospheric and oceanic components are linked by a coupler, which calculates and interpolates fluxes between the two components (Tobis et al., 1997). FOAMv1.5 compares well with other generalised climate models for present-day climate (Jacob, 1997) and has also proven to be useful in the study of past climates (Poulsen et al., 2001; Donnadieu et al., 2006; Zhang et al., 2011; Chaboureau et al., 2012; Hamon et al., 2012; Lefebvre et al., 2012). Moreover, a recent study showed that FOAMv1.5 simulates a modern ACC which is in good 


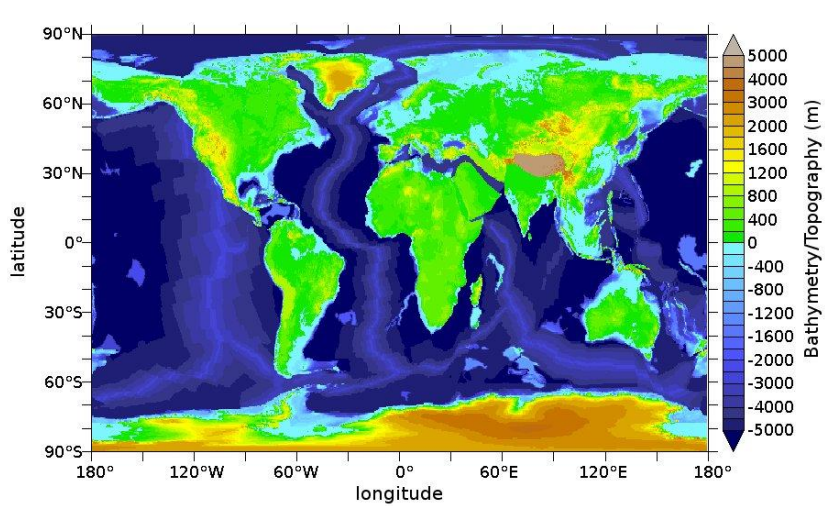

Fig. 1. Middle Miocene geography used in the Mio4000 experiment (Tethys seaway depth $=4000 \mathrm{~m}$ ).

Table 1. Tethys seaway depth for each of the four sensitivity experiments.

\begin{tabular}{lr}
\hline Experiment & Tethys seaway depth (m) \\
\hline Mio4000 & 4000 \\
Mio1000 & 1000 \\
Mio250 & 250 \\
MioC & 0 (closed seaway) \\
\hline
\end{tabular}

agreement with observations and with coupled models from the IPCC AR4 (Lefebvre et al., 2012).

Our middle Miocene simulations are forced with a palaeogeography derived from Herold et al. (2008). The main differences compared to the present-day geography are lower reliefs, an open Central American Isthmus, a closed Bering Strait and a southward shift of Australia (Fig. 1). All the four experiments presented here were performed using the same palaeogeography, except for the eastern Tethys seaway depth. In order to test the impact of the Tethys seaway closure on oceanic circulation and climate, we performed four sensitivity experiments with various gateway depth (Table 1). The width of the gateway was unchanged between experiments.

The Miocene vegetation is based on Wolfe (1985) and is the same as used in previous studies on middle Miocene climate (Tong et al., 2009; You et al., 2009; Herold et al., 2009; Hamon et al., 2012). Important changes compared to present-day vegetation are the absence of desert, the larger latitudinal expansion of tropical and subtropical forests as well as the replacement of ice by boreal forest in Greenland. The atmospheric $\mathrm{CO}_{2}$ concentration during the middle Miocene is still highly debated (Cerling, 1991; Pagani et al., 1999, 2009; Pearson and Palmer, 2000; Royer et al., 2001; Kürschner et al., 2008; Kürschner and Kvacek, 2009; Tripati et al., 2009; Foster et al., 2012; Badger et al., 2013). Recent modelling studies concluded that higher-than-present $p \mathrm{CO}_{2}$ is necessary to simulate a middle Miocene climate consistent with data (Tong et al., 2009; You et al., 2009; Henrot et al., 2010; Krapp and Jungclaus, 2011; Herold et al., 2011; Ha-
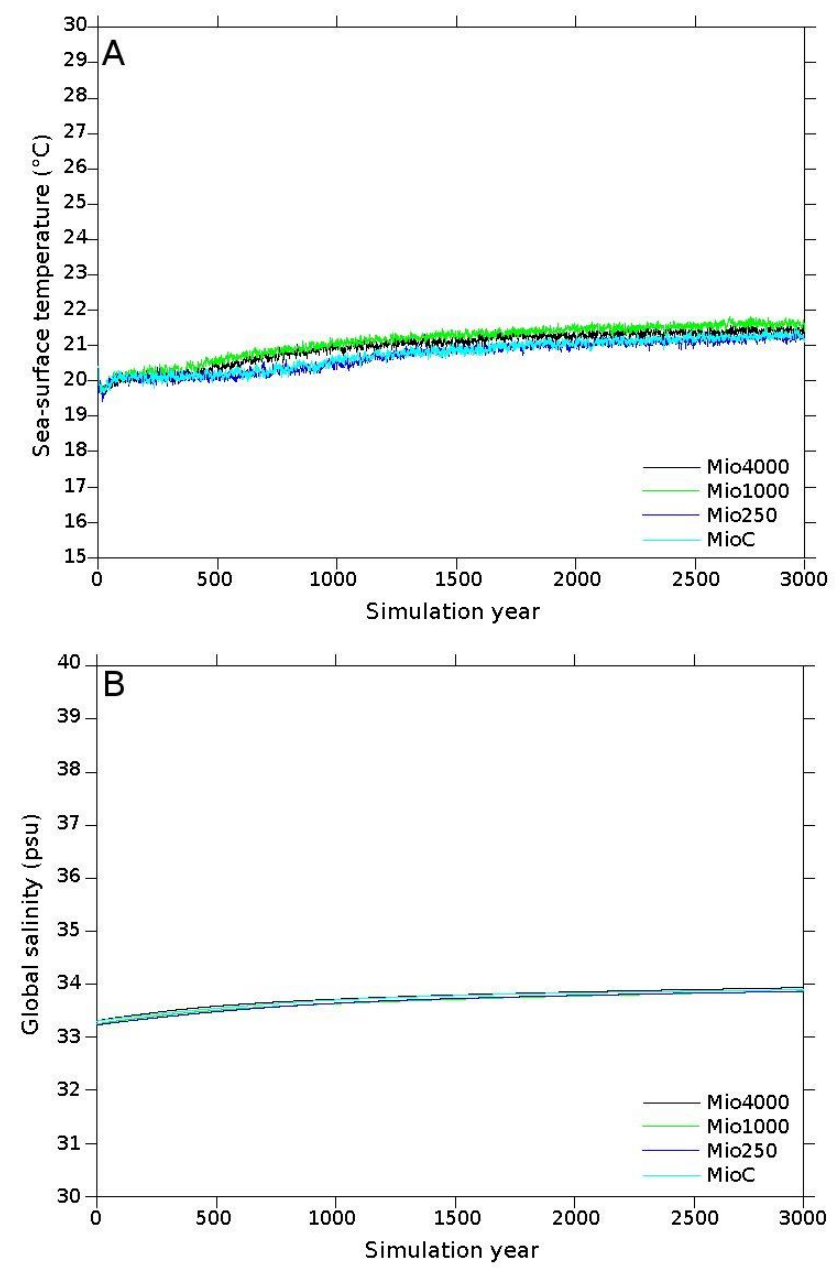

Fig. 2. Evolution of (A) sea-surface temperature $\left({ }^{\circ} \mathrm{C}\right)$ and $(\mathbf{B})$ global salinity (psu) during the four Miocene experiments.

mon et al., 2012). Moreover, using the model FOAMv1.5, Hamon et al. (2012) showed that Miocene European climate and vegetation are more consistent with data when the $p \mathrm{CO}_{2}$ is equal to $560 \mathrm{ppmv}$. In our four middle Miocene simulations, we therefore used this concentration. Solar constant, orbital parameters, $p \mathrm{CH}_{4}$ and $p \mathrm{~N}_{2} \mathrm{O}$ were kept at their modern values.

All the experiments were integrated for $3000 \mathrm{yr}$ without flux correction. The Atlantic Meridional Overturning Circulation was stable during the last $500 \mathrm{yr}$. Temperature and salinity trends for the four Miocene experiments are shown in Fig. 2. We use the average of the last $30 \mathrm{yr}$ of each simulation for our analyses. 


\section{Results}

\subsection{Mediterranean-Indian exchange and TISW formation}

In the four Miocene experiments, the river transport was prescribed to maximise the potential run-off incoming to the Paratethys and the Mediterranean basins. Coastal river flow is the strongest in the northern part of the Paratethys, inducing very low salinity in the region (Fig. 3). However, due to the combination of high evaporation rates and weak southward water current from the Paratethys to the Mediterranean Basin, the latter is rather insensitive to the river run-off. Over the Mediterranean Basin, the negative precipitation minus evaporation balance therefore leads to surface salinities scaling up to 37.5 psu (Fig. 3). The three experiments with an open Tethys seaway depict a northward surface inflow entering the Tethys gateway (Fig. 4). This inflow is linked to wind stress induced by boreal summer Indian monsoon winds that blow off the northeastern African coast (Fig. 5). In deepopen experiments (Mio4000 and Mio1000), this northward flow is restricted to the first $500 \mathrm{~m}$, while below this depth a strong countercurrent, driven by salinity gradient between the saline Mediterranean Basin and relatively fresher Indian Ocean, brings water masses southward (Figs. $4 \mathrm{c}$ and 6).

This result is consistent with a previous modelling study showing no northward water flux in the Tethys seaway below $500 \mathrm{~m}$ (Fig. 11 in Butzin et al., 2011). However, most modelling studies (von der Heydt and Dijkstra, 2005; Herold et al., 2012, e.g.) depict an overall net flow in the Tethys seaway that is oriented towards the Mediterranean Basin, with water transported from the Indian Ocean to the Atlantic through the proto-Mediterranean. In our simulations, the reversed flow ranges between $5.5 \mathrm{~Sv}$ (Mio4000) and 7.4 Sv (Mio1000), leading to an overall net southward outflow of 1.5-2 Sv (Fig. 4c and Table 2). This flow reversal in the eastern Tethys seaway in the Mio4000 and Mio1000 experiments is due to the eastward water transport in the "Gibraltar" Strait (Fig. 4a), which does not allow the transport of water from the Indian Ocean towards the Atlantic. This is explained by (i) the difference of bathymetry between the Tethys seaway (respectively 4000 and $1000 \mathrm{~m}$ ) and the Gibraltar Strait $(400 \mathrm{~m})$ and (ii) the inflow of surface water coming from the subtropical Atlantic gyre to the Gibraltar Strait that induces eastward transport (Fig. 3). The outflow from the eastern Tethys gateway induces the onset of warm and salty (up to 37.7 psu at $1000 \mathrm{~m}$ depth) waters in the Indian Ocean (Figs. 6 and 7), which is consistent with the TISW described on the basis of isotopic data (Woodruff and Savin, 1989; Wright et al., 1992; Flower and Kennett, 1994; Ramsay et al., 1998).

Conversely, the shallow bathymetry of the Mio250 experiment allows only a weak subsurface northward current to flow in the eastern Tethys gateway and prevents any southward countercurrent to develop, thereby precluding the formation of TISW (Figs. 4c, 6 and 7). As a consequence,
Table 2. Northward water transport (Sv) in the Tethys seaway, and eastward water transport (Sv) in Gibraltar, Drake and Tasmanian seaways for each of the four Miocene experiments.

\begin{tabular}{lrrrr}
\hline Experiment & Eastern Tethys & Gibraltar & Drake & Tasmanian \\
\hline Mio4000 & -1.7 & 2.6 & 43.0 & 62.8 \\
Mio1000 & -2.0 & 2.6 & 40.1 & 61.2 \\
Mio250 & 2.7 & -2.8 & 47.1 & 66.9 \\
MioC & - & 0 & 51.3 & 71.5 \\
\hline
\end{tabular}

compared to the two deep-open experiments Mio4000 and Mio1000, Mio250 depicts a cooling and freshening of the Indian Ocean that spreads down to $3000 \mathrm{~m}$ and to $60^{\circ} \mathrm{S}$ (Fig. 8), whereas the Mediterranean Basin displays higher salinity.

Mio250 and MioC experiments exhibit very similar patterns of temperature and salinity in the Indian Ocean, suggesting that only a deep Tethys seaway can produce the TISW (Fig. 7). However, the two simulations differ regarding the proto-Mediterranean salinity: Mio250 surface flow from the Indian Ocean to the Gibraltar Strait produces surface salinities that are 1 psu lower than the values simulated with a semi-enclosed Mediterranean Basin (experiment MioC).

Between the Mio4000 and MioC experiments, there is only a non-significant change of the heat transport in the Indian Ocean (less than $0.02 \mathrm{PW}$ ). Therefore the first hypothesis according to which the termination of TISW production decreased oceanic heat transport towards the Southern Ocean, allowing the East Antarctic Ice Sheet expansion (Woodruff and Savin, 1989; Flower and Kennett, 1994, 1995), is not consistent with our results.

\subsection{Mediterranean-Atlantic exchange and AMOC}

In Mio4000 and Mio1000, the entire water flux through the Gibraltar Strait flows from the Atlantic to the Mediterranean Basin (Figs. 3, 4a and 6). This is consistent with the results of Karami et al. (2009), which indicate a west-to-east deep flow in both Gibraltar and eastern Tethys gateways prior to the Tethys seaway closure. In our experiments, the Tethys seaway shoaling to $250 \mathrm{~m}$ induces a flow reversal, producing a net outflow to the Atlantic of approximately $2.8 \mathrm{~Sv}$ (Table 2 ). The flow reversal in the Gibraltar gateway is also simulated in the box model experiments from Karami et al. (2009) when the eastern Tethys seaway is closed. With this outflow, Atlantic Intermediate Water, between 750 and $2000 \mathrm{~m}$, is warmer and saltier than in deep-open Tethys seaway experiments (Fig. 8).

When the Tethys seaway is fully closed, protoMediterranean-Atlantic exchange is rather similar to modern Mediterranean-Atlantic exchange, with a surface eastward flow of North Atlantic Water in the Mediterranean Basin and a deeper (between 200 and $400 \mathrm{~m}$ ) westward flow into the Atlantic (Fig. 4a). The latter outflow feeds the North Atlantic in a similar way to the Mio250 experiment, but the temperature 

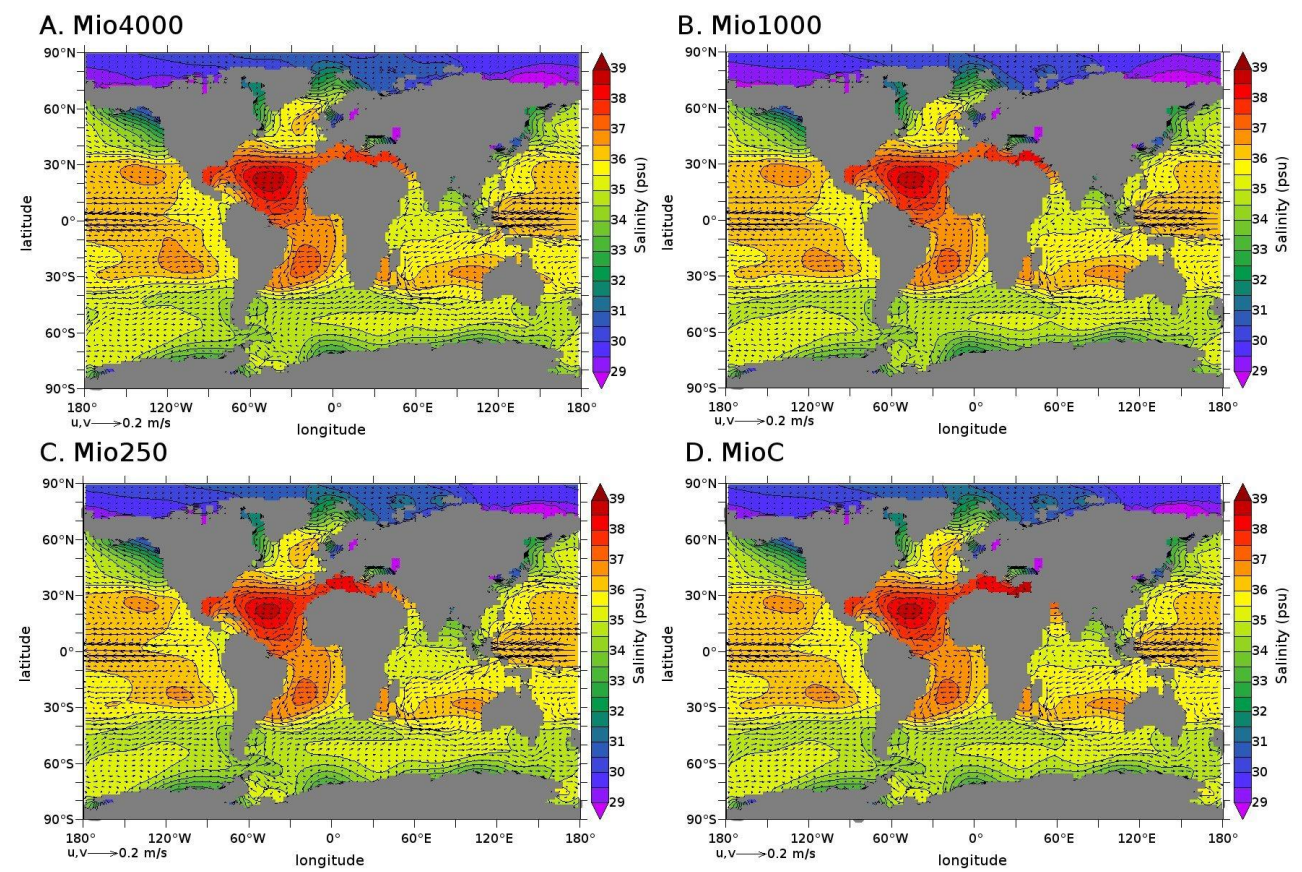

Fig. 3. Simulated annual salinity (psu) averaged over the top $100 \mathrm{~m}$ of the water column. Vectors indicate annual surface horizontal flow $\left(\mathrm{ms}^{-1}\right)$. (A) Mio4000, (B) Mio1000, (C) Mio250 and (D) MioC.

and salinity anomalies compared to the Mio4000 experiment do not reach the western boundary of the Atlantic Basin. However, in both Mio250 and MioC, the southern part of the Atlantic Meridional Overturning Circulation (AMOC), indicated by the meridional stream function, is enhanced compared to Mio4000 (Fig. 9). This result is consistent with a recent study suggesting that the input of warm and saline water from the Mediterranean Sea strengthens the AMOC (Ivanovic et al., 2013).

Oceanic heat transport in the Atlantic is very similar between the experiments with deep-open (Mio4000) and closed (MioC) eastern Tethys seaway, as this is the case in the Indian Ocean. The third hypothesis, according to which the closure of the Tethys seaway provoked an enhancement of NADW production and meridional heat transport (Wright et al., 1992), is therefore partly consistent with our results. Despite the observed reinforcement of the AMOC between our experiments Mio4000 and MioC, no significant increase of heat transport in the Atlantic Ocean is simulated.

\subsection{Southern Ocean}

The presence or absence of TISW in the Indian Ocean influences the latitudinal patterns of density. Figure 10a shows the vertical profile of the potential density anomaly between a southern box and a northern box in the Indian Ocean. It indicates that the absence of TISW in experiments Mio250 and MioC induces a stronger latitudinal density gradient. In turn, this gradient produces stronger meridional advec- tion (not shown) and enhanced geostrophic westerly volume transport between depths of $200 \mathrm{~m}$ and $2800 \mathrm{~m}$ (Fig. 11), which corresponds to a strengthening of the ACC. Moreover, the intensification of the AMOC due to the closure of the eastern Tethys seaway may increase the pressure gradient in the Atlantic Ocean and reinforce the ACC. The shoaling to $250 \mathrm{~m}$ and the full closure of the Tethys seaway increase the total ACC volume transport in the Drake Passage and Tasmanian gateway by $4.1 \mathrm{~Sv}$ and $8.8 \mathrm{~Sv}$ respectively (i.e. $6.4 \%$ and $13.9 \%$ respectively) when compared to Mio4000 (Table 2). As a consequence sea-surface temperatures are lower and sea-ice extent is increased, which produces denser water at southern high latitudes, therefore enhancing the latitudinal density gradient. Moreover, these colder surface temperatures affect the atmosphere and make the latitudinal thermal gradient stronger, ultimately reinforcing the westerlies' strength, a positive feedback for the ACC.

These results are consistent with the second hypothesis presented above. The closure of the eastern Tethys seaway and the termination of TISW production induces an acceleration of the ACC in our experiments. Moreover, in a recent study, Holbourn et al. (2013) highlighted a reinforcement of Pacific meridional overturning circulation and suggest that it was due to increased deep-water formation in the Southern Ocean. The reinforcement of the ACC simulated in our Mio250 and MioC experiments increases the convection in the Southern Ocean, and is therefore consistent with the results of Holbourn et al. (2013). 

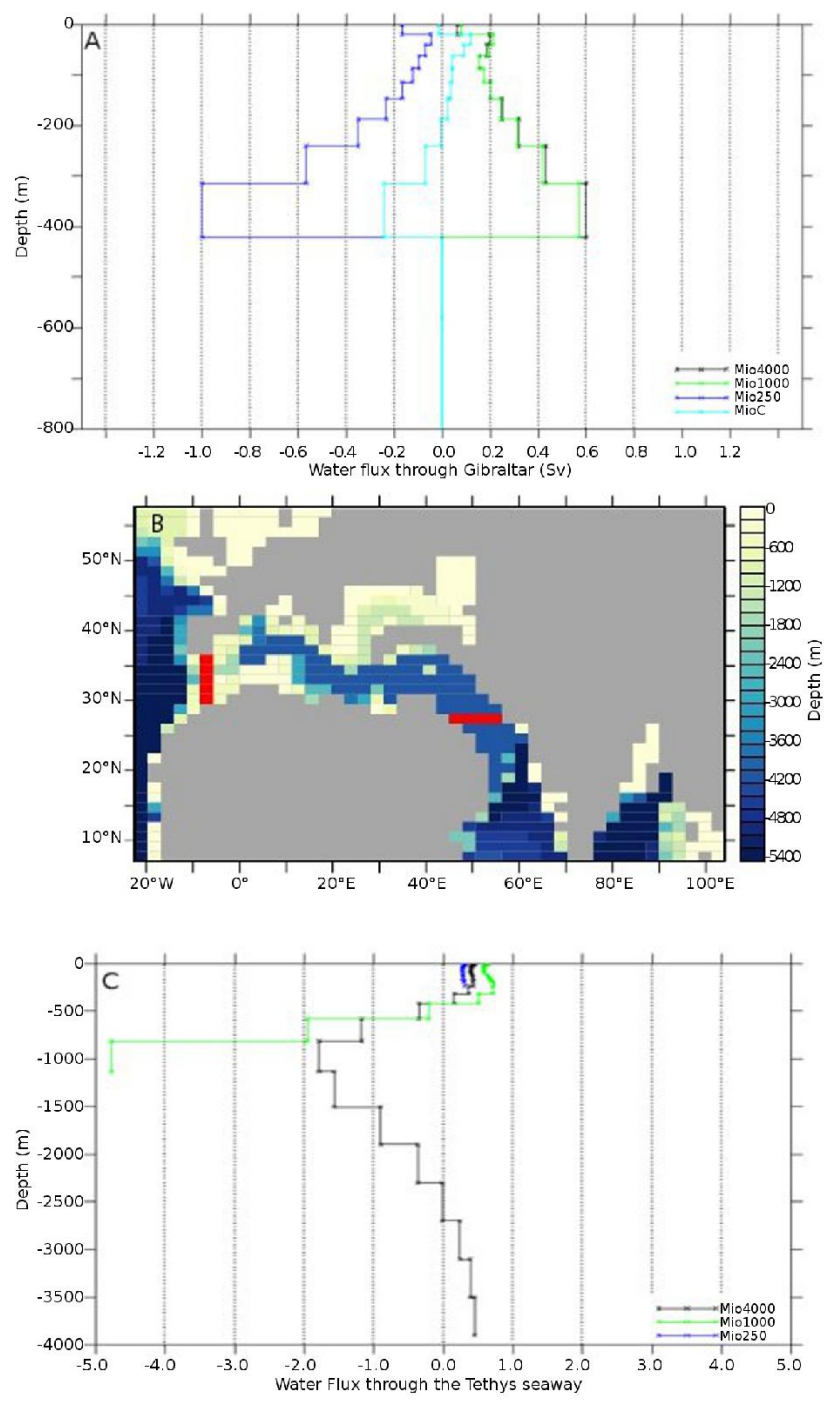

Fig. 4. (A) Zonal water transport through Gibraltar seaway (Sv). Positive values indicate eastward transport; negative values indicate westward transport. (B) Focus on bathymetry used in open Tethys seaway experiments. Red segments indicate grid points where water transports have been computed. (C) Meridional water transport through eastern Tethys seaway (Sv). Positive values indicate northward transport; negative values indicate southward transport.

\subsection{Antarctic climate}

The reorganisation of oceanic circulation due to the shoaling and closure of the eastern Tethys seaway provokes surface temperature variations, especially over Antarctica. The decrease of sea-surface temperatures in the Southern Ocean and the reinforcement of the ACC induce an annual mean cooling of approximately 0.1 to $2.5^{\circ} \mathrm{C}$ over Antarctica between the experiments Mio4000 and MioC (Fig. 12a). Moreover, the warmest month temperature is up to $1.3^{\circ} \mathrm{C}$ colder when the eastern Tethys seaway is closed, which should limit the ablation of the ice sheet during summer (Fig. 12b).
However, temperature variations are small and only nonsignificant precipitation variations occur over Antarctica between Mio4000 and MioC (lower than $100 \mathrm{~mm} \mathrm{yr}^{-1}$, not shown). Although consequences for Antarctica ice-sheet building remain to be tested with a dedicated ice-sheet model, the weak changes of temperatures and precipitation between Mio4000 and MioC simulated over Antarctica suggest that the Tethys seaway closure unlikely initiated the East Antarctic Ice Sheet expansion during the middle Miocene. Moreover, data-based reconstructions estimate that deep water $(1700 \mathrm{~m})$ cooled by approximately $3{ }^{\circ} \mathrm{C}$ during the MMCT (Billups and Schrag, 2002), whereas the global deep-water cooling between the experiments Mio4000 and MioC is only $-0.7^{\circ} \mathrm{C}$. These results strongly suggest that the closure of the Tethys seaway was not the only driver of the MMCT.

\section{Discussion}

\subsection{Impact of eastern Tethys seaway closure on Miocene ocean and climate}

Three different hypotheses have been proposed to explain the way the eastern Tethys seaway closure allowed Antarctic ice-sheet growth during the MMCT. First, the termination of the TISW production should have provoked a decrease in southward heat transport (Woodruff and Savin, 1989; Flower and Kennett, 1994, 1995). Although we simulate a cooling of the Indian Ocean when the Tethys seaway depth does not allow TISW production (Fig. 8), the oceanic heat transport in the Indian Ocean displays only non-significant variations between the four experiments. Secondly, the termination of TISW production should have induced the acceleration of the ACC (Flower and Kennett, 1995; Kuhnert et al., 2009; Verducci et al., 2009). Our simulations depict the full mechanism leading from the Tethys seaway closure to the ACC acceleration, which is in good agreement with this data-derived hypothesis. Finally, it was proposed that the closure of the eastern Tethys seaway enhanced the AMOC and meridional heat transport in the Atlantic Ocean, increasing evaporation in the Southern Ocean and therefore precipitation over Antarctica (Wright et al., 1992). Although our results are congruent with a reinforcement of the AMOC, simulated response to Tethys seaway closure do not show significant changes in precipitation over Antarctica.

The results of our sensitivity experiments indicate the existence of TISW when the eastern Tethys seaway is deep open, whereas a shallow or closed seaway prevents the production of this water mass. We also highlight major changes in oceanic circulation due to eastern Tethys shoaling and closure. However, the consequences for global and the Antarctic climate remain too weak to explain the expansion of the ice sheet. Therefore we suggest that TISW termination had a 

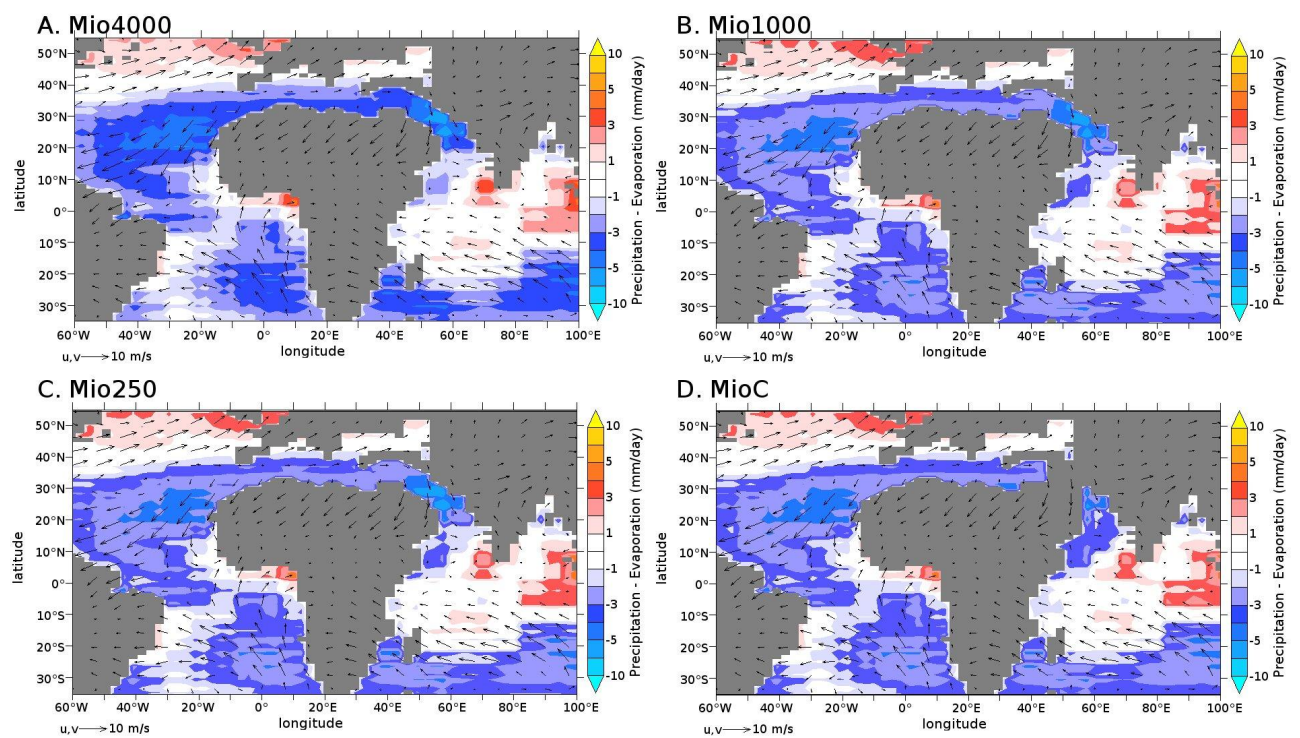

Fig. 5. Simulated boreal summer precipitation minus evaporation rate $\left(\mathrm{mm} \mathrm{day}^{-1}\right)$. Vectors indicate summer surface wind speed $\left(\mathrm{ms}^{-1}\right)$. (A) Mio4000, (B) Mio1000, (C) Mio250 and (D) MioC.
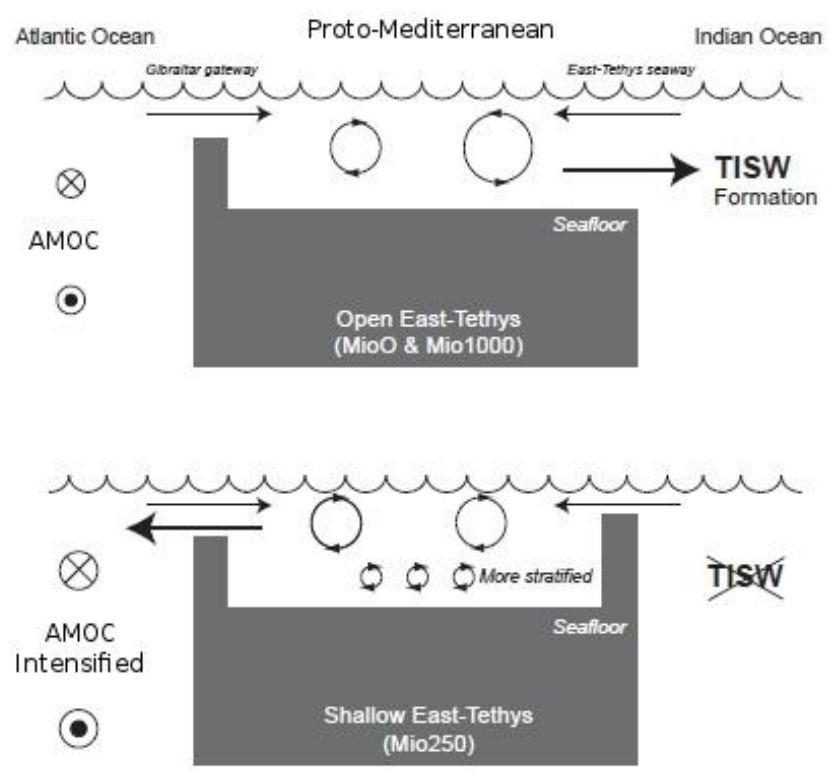

Fig. 6. Schematic view of oceanic circulation between the Indian Ocean, the proto-Mediterranean and the Atlantic Ocean when the eastern Tethys seaway is deep open (top panel) and when it is shallow (bottom panel).

significant impact on global oceanic circulation but was not the driver of the MMCT.

Several modelling studies have investigated the impact of geographic changes, and in particular seaways closure, on Cenozoic cooling (von der Heydt and Dijkstra, 2005; Zhang et al., 2011; Butzin et al., 2011). However, two obstacles prevent a reliable inter-comparison: the difference in model complexity and the palaeogeography and experiment design involved. In this section we discuss some characteristics of previous studies to emphasise the need for an intercomparison project on the modelling of the impact of ocean gateways on climate. von der Heydt and Dijkstra (2005, 2006) performed sensitivity experiments to study the impact of closing the eastern Tethys seaway on Caribbean oceanic circulation and temperatures. Their experiments particularly depict an overestimated ACC, relatively low water transport in the Panama seaway and a net water flow in the Tethys seaway which is oriented from the Atlantic to the Indian Ocean (von der Heydt and Dijkstra, 2005). These results are consistent with an open Tethys experiment carried out with a later version of the model used in von der Heydt and Dijkstra (2005, 2006) - CCSM3 - (Herold et al., 2012) but differ from ours, which depicts a weak eastward Mediterranean throughflow and a strong eastward transport through Panama (not shown). The diverging responses with the von der Heydt and Dijkstra (2005) study can be explained by important palaeogeography differences (they used idealised flat-bottom ocean $(5000 \mathrm{~m})$ and two geographic configurations corresponding to the late Oligocene and the early Miocene). However, our palaeogeography being the same as used in Herold et al. (2012), differences with the latter are more likely linked to model parameterisation and ocean-atmosphere coupling. Using a three-box model, Karami et al. (2009) found a water flow oriented from the west to the east in the eastern Tethys seaway. They also demonstrated that the flow in this seaway was driven by the density gradient between the basins. In our experiments, the Mediterranean Basin is characterised by high density, mainly due to the high salinity. In the experiment from Herold et al. (2012), salinity in the Mediterranean 
A

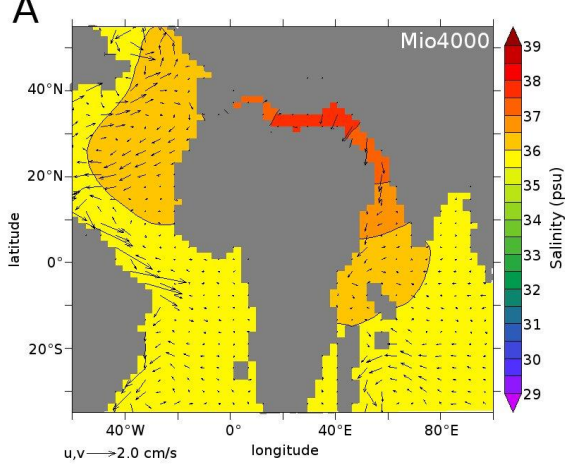

C

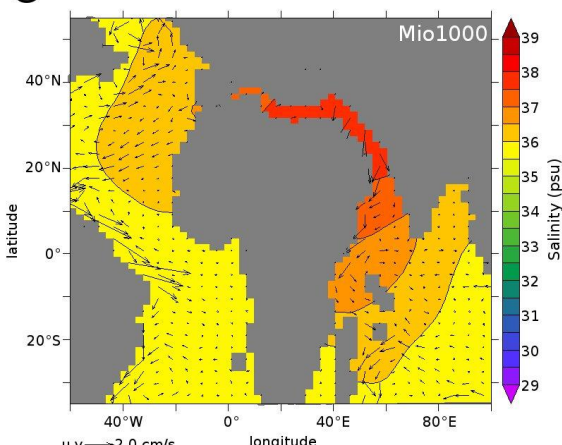

E

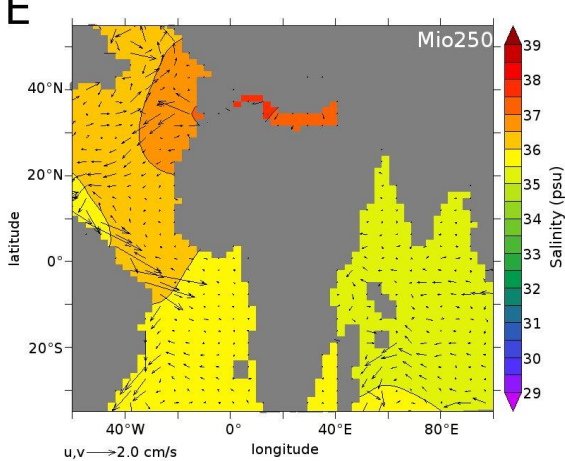

G

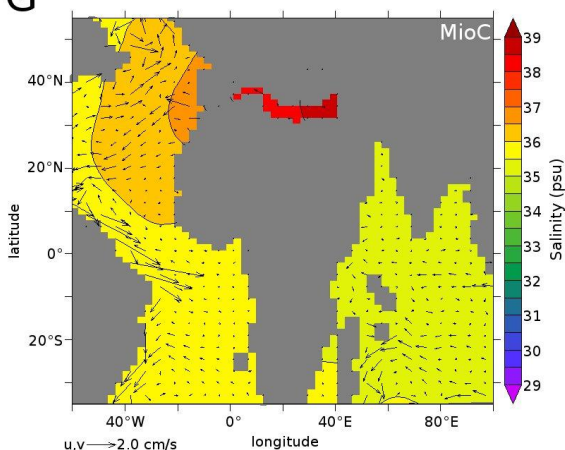

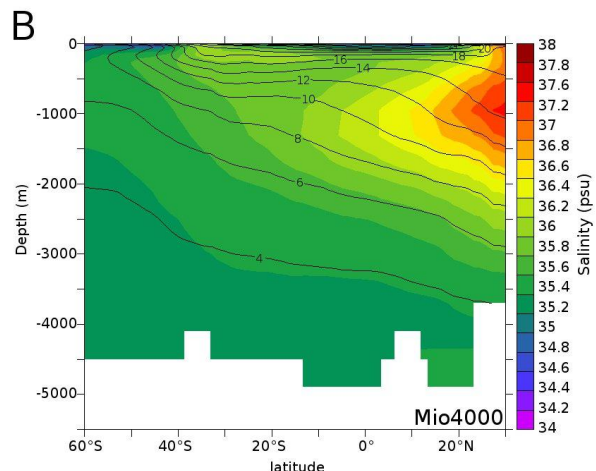

D

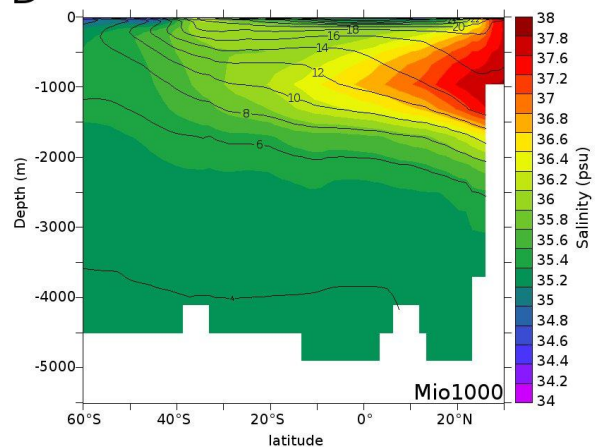

$\mathrm{F}$

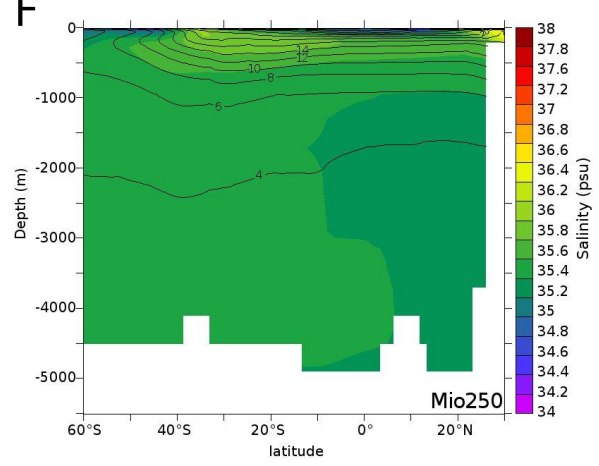

$\mathrm{H}$

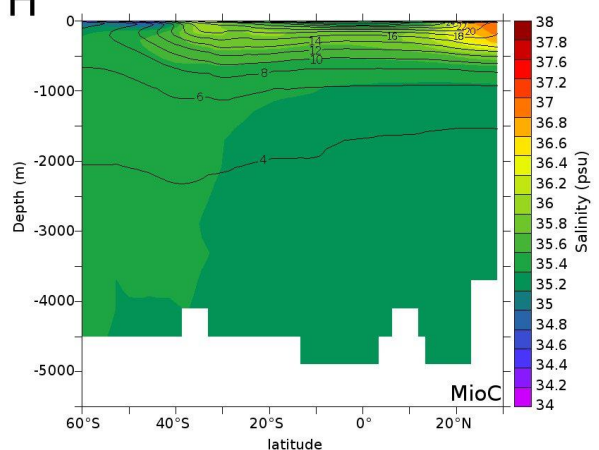

Fig. 7. (A, C, E, G) Simulated annual salinity at $952 \mathrm{~m}$ and horizontal flow $\left(\mathrm{cm} \mathrm{s}^{-1}\right)$ for Mio4000, Mio1000, Mio250 and MioC, respectively. $(\mathbf{B}, \mathbf{D}, \mathbf{F}, \mathbf{H})$ Simulated salinity (shaded colours, psu) and temperature (isolines, ${ }^{\circ} \mathrm{C}$ ) as a function of depth averaged between $45^{\circ} \mathrm{E}$ and $60^{\circ} \mathrm{E}$, for Mio4000, Mio1000, Mio250 and MioC, respectively. 

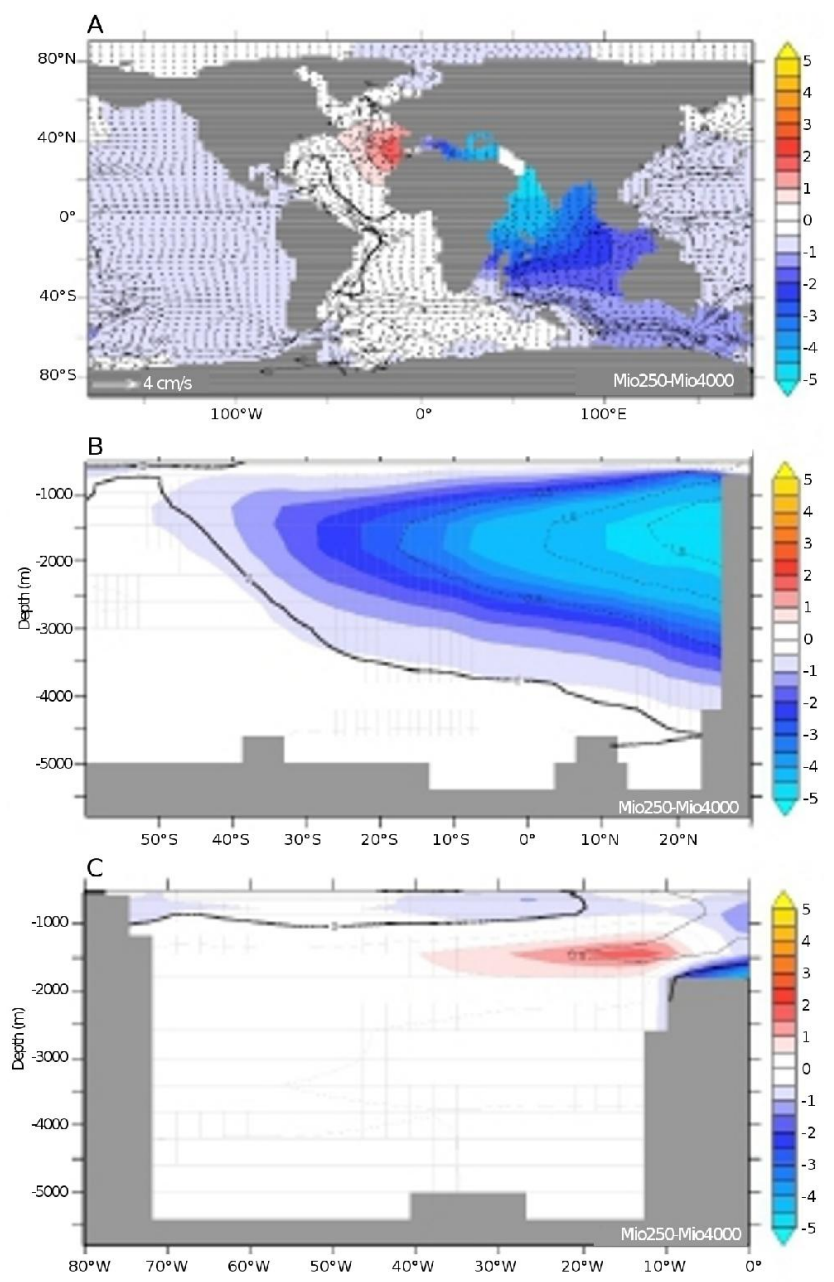

Fig. 8. (A) Simulated temperature difference at $952 \mathrm{~m}$ between Mio250 and Mio4000 experiments. Vectors indicate Mio4000 horizontal flow. (B) Mio250-MioC anomaly of temperature (shaded colours, ${ }^{\circ} \mathrm{C}$ ) and salinity (isolines, psu) as a function of depth, averaged between $45^{\circ} \mathrm{E}$ and $60^{\circ} \mathrm{E}$. (C) Mio250-MioC anomaly of temperature (shaded colours, ${ }^{\circ} \mathrm{C}$ ) and salinity (isolines, psu) as a function of depth, averaged between $30^{\circ} \mathrm{N}$ and $40^{\circ} \mathrm{N}$.

is lower, which can explain the flow reversal in the Tethys seaway compared to our deep open experiments.

Using an ocean circulation carbon cycle model of intermediate complexity, Butzin et al. (2011) performed sensitivity experiments on various eastern Tethys and Panama gateways configurations. Comparable with our study, water fluxes through the Tethys seaway are northward in surface and southward in depth. By suppressing this southward water transport, the closure of the Tethys seaway leads to a cooling of up to $4^{\circ} \mathrm{C}$ between 500 and $2000 \mathrm{~m}$, a result consistent with ours and with data (Zachos et al., 2001; Billups and Schrag, 2002). However, according to Butzin et al. (2011), this pattern strongly depends on the width of the Tethys seaway; a narrow Tethys seaway produces an equilibrated

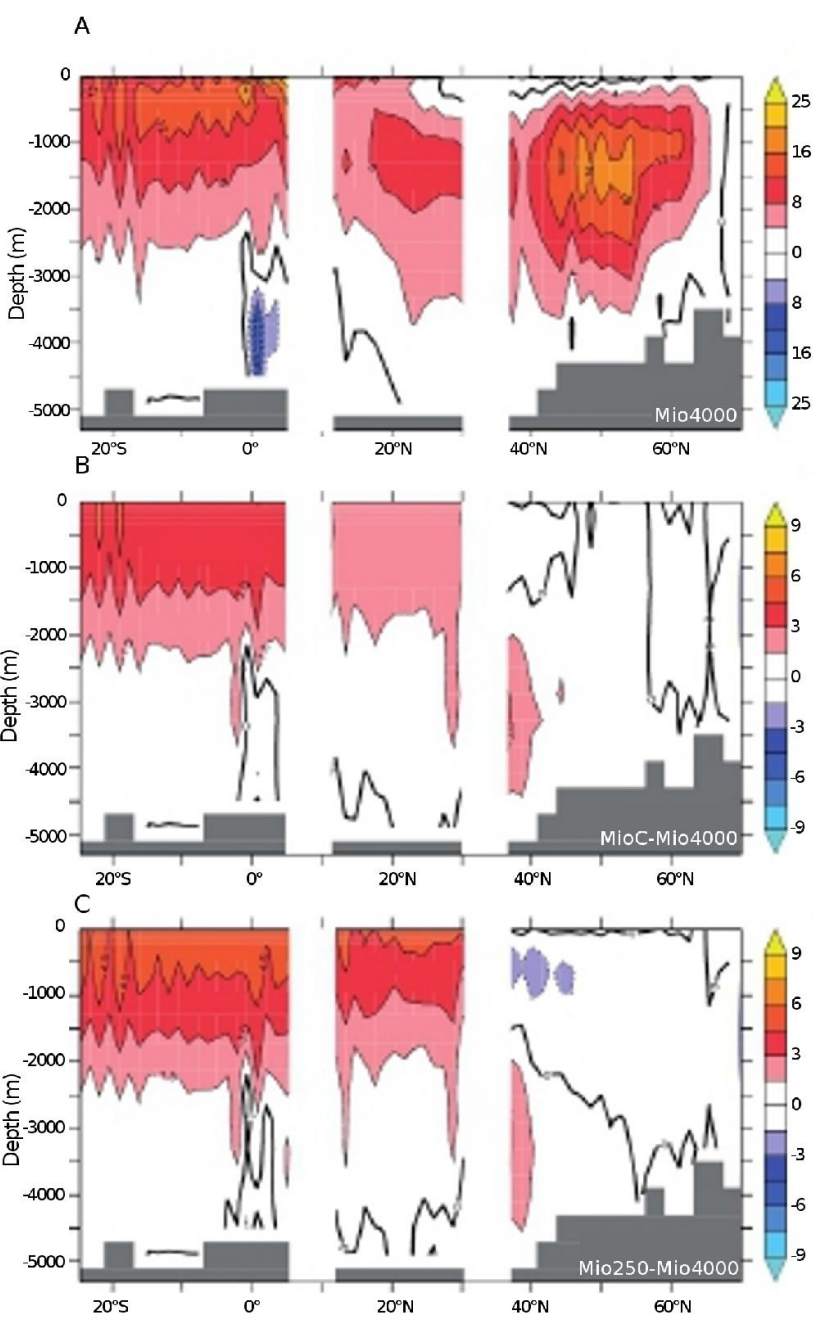

Fig. 9. (A) Simulated Atlantic meridional stream function for Mio4000 experiment. (B) MioC-Mio4000 Atlantic stream function anomaly. (C) Mio250-Mio4000 Atlantic stream function anomaly. Regions where divergence is not equal to zero have been masked.

throughflow (i.e. net flow approximately $0 \mathrm{~Sv}$ ), whereas a wide Tethys seaway leads to a surface northern flow that overcomes the deeper southern flow. Consequently Butzin et al. (2011) find no large-scale impact of the eastern Tethys seaway closure, especially on the ACC.

Our results highlight an intensification of the ACC when the Tethys seaway is closed compared to when it is open (Table 2), which is consistent with data-based reconstructions of oceanic circulation changes during the MMCT (Shevenell et al., 2004; Kuhnert et al., 2009). This discrepancy between model results can be due either to the difference in the boundary conditions (Butzin et al., 2011, used present-day geography with modified seaways and the ocean model they use is forced by present-day wind fields) or to the models themselves. New simulations and model inter-comparison should help us to understand the cause of this discrepancy between 

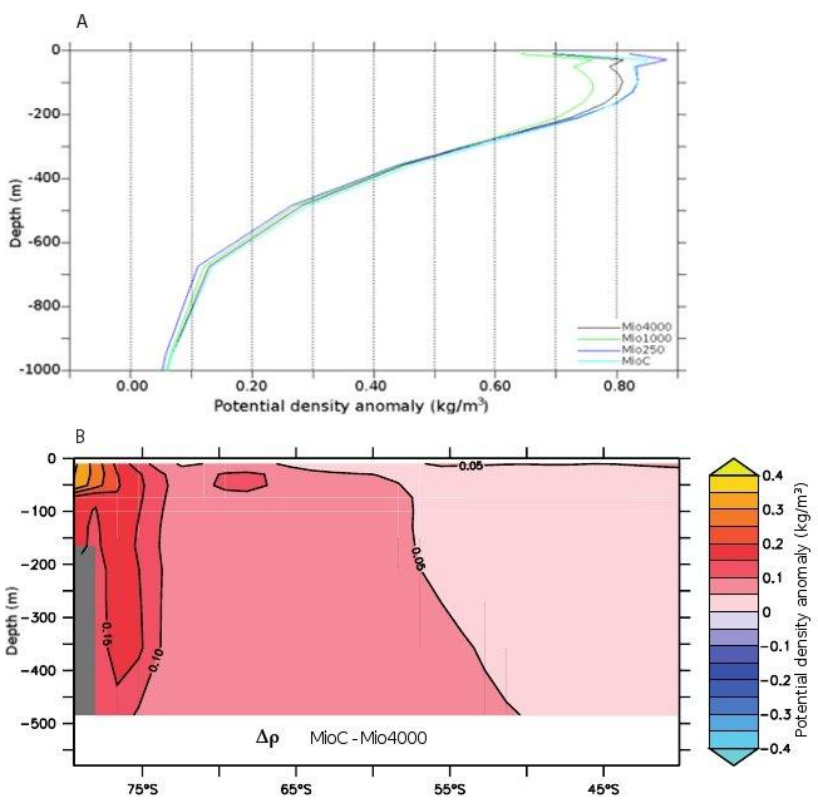

Fig. 10. (A) Simulated potential density $\left(\mathrm{kg} \mathrm{m}^{-3}-1000\right)$ anomaly between a southern box $\left(70-55^{\circ} \mathrm{S}\right)$ and a northern box $\left(55-35^{\circ} \mathrm{S}\right)$ in the Indian Ocean $\left(40-75^{\circ} \mathrm{E}\right)$, as a function of depth. (B) Simulated potential density anomaly $\left(\mathrm{kg} \mathrm{m}^{-3}\right)$ between MioC and Mio4000 in the Indian Ocean.

our results and those of Butzin et al. (2011). Moreover, the results of Butzin et al. (2011) indicate that the width of the Tethys seaway is a crucial boundary condition, whereas, using the same seaway width for all experiments, we showed that its depth also plays an important role. A more detailed reconstruction of the Tethys seaway configuration at diverse time periods should help us to better constrain the impact of this seaway closure on the global oceanic circulation during the middle Miocene.

The temperature changes in the Indian Ocean between the MioC and Mio4000 experiments, in particular the strong cooling in deep water, are congruent with the results of Butzin et al. (2011) and with data (Zachos et al., 2001; Billups and Schrag, 2002). However, the non-significant heat transport variations due to the closure of the Tethys seaway cannot provide a satisfying explanation for the rapid growth of the East Antarctic Ice Sheet, and the global cooling simulated between the Miocene experiments is too weak compared to the cooling deduced from data (Zachos et al., 2001; Billups and Schrag, 2002). Therefore the closure of the eastern Tethys seaway was probably not the main cause of the MMCT, and other mechanisms should be tested to better understand this climatic transition.

\subsection{Timing of the eastern Tethys seaway closure}

Many authors agree that the final closure of the eastern Tethys seaway, and the subsequent end of water exchanges
A
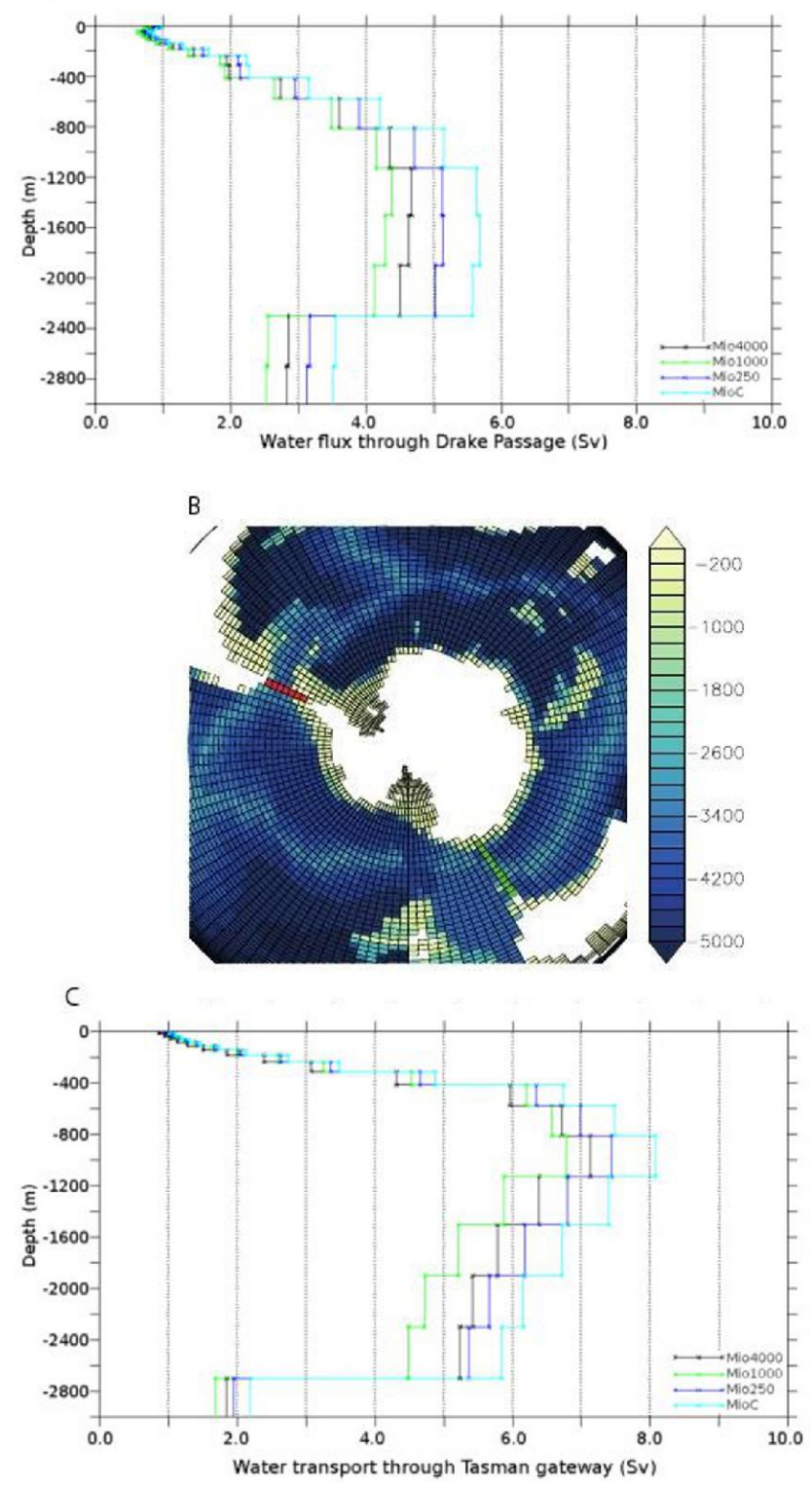

Fig. 11. (A, C) Zonal water transport through Drake (A) and Tasman (C) gateways, for the four experiments. (B) Focus on bathymetry used in all experiments. Coloured segments indicate grid points where water transports have been computed.

between the proto-Mediterranean and the Indian Ocean, occurred during the middle Miocene, at approximately $14 \mathrm{Ma}$ (Rögl, 1999; Harzhauser and Piller, 2007; Harzhauser et al., 2007, 2009). This age estimation coincides with the Middle Miocene Climatic Transition, and is one of the arguments supporting the hypothesis of the Tethys seaway closure as a driver of this transition (Woodruff and Savin, 1989; Wright et al., 1992; Flower and Kennett, 1995; Ramsay et al., 1998). However, Hüsing et al. (2009) suggested that the Tethys seaway final closure occurred at approximately $11 \mathrm{Ma}$, which is 

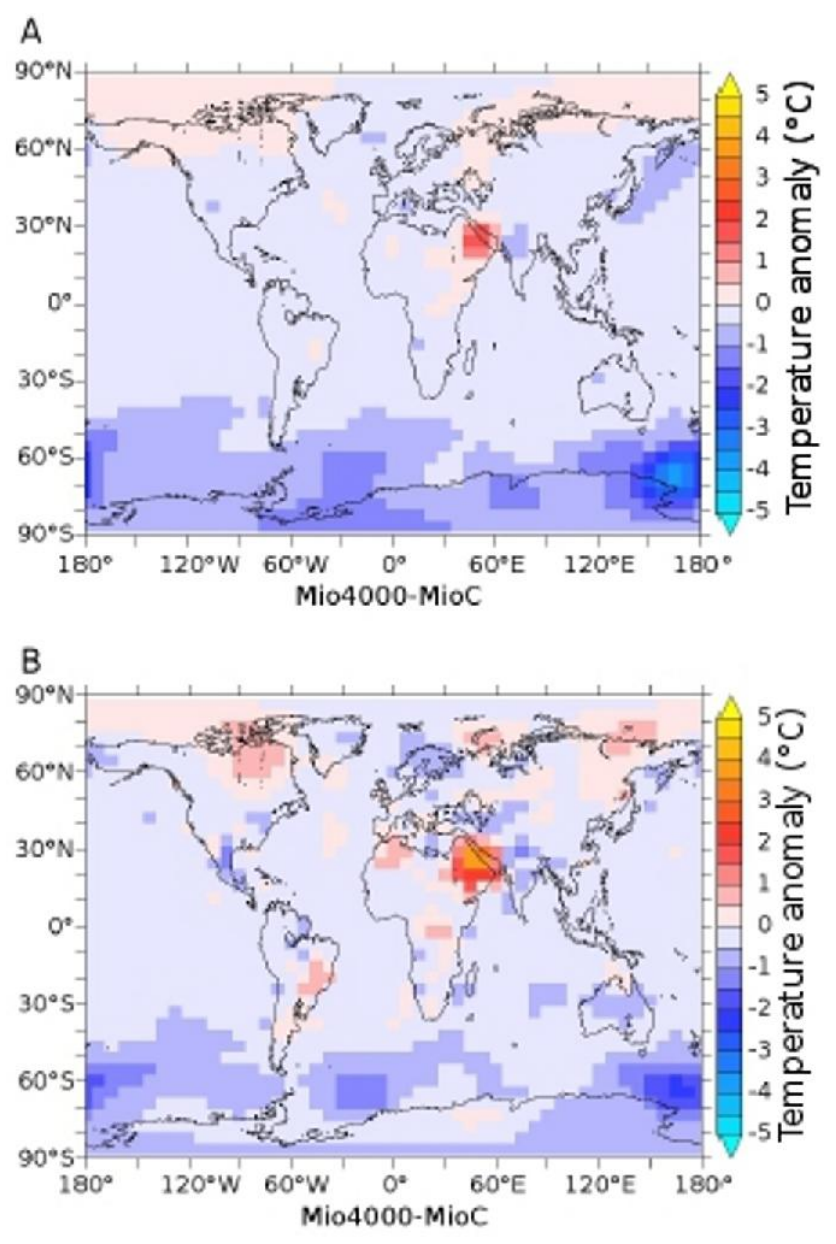

Fig. 12. Annual mean surface air temperature anomaly $\left({ }^{\circ} \mathrm{C}\right)$ : MioCMio4000.

much younger than the previous estimations. However, this age estimate comes from the westernmost transect of the seaway (southern Turkey) and, because of diachronous collision between Afro-Arabia and Eurasia, this region still could have been deep marine whereas the easternmost part of the seaway was closed (Hüsing et al., 2009). They particularly suggested that deep marine conditions prevailed in this region during the early Tortonian (approximately $11 \mathrm{Ma}$ ), providing a gateway between the Mediterranean and Indian Ocean along the northern margin of Arabia (Hüsing et al., 2009).

Stable isotope composition of marine carbonates indicate the existence of TISW in the Indian Ocean during the early and middle Miocene (Woodruff and Savin, 1989; Wright et al., 1992; Flower and Kennett, 1994, 1995). In the present study, we demonstrate that TISW cannot be produced when the Tethys seaway is shallow $(250 \mathrm{~m}$ depth in our model experiments), water transport being from the Indian Ocean towards the Mediterranean Basin in the Mio250 experiment. Therefore we suggest that, prior to approximately $14 \mathrm{Ma}$, a relatively deep seaway connected the Indian
Ocean and the proto-Mediterranean, allowing the production of TISW. Moreover, the termination of TISW production during the MMCT (Woodruff and Savin, 1989; Wright et al., 1992; Flower and Kennett, 1994, 1995) suggests a middle Miocene age for the final closure of the Tethys seaway, which is consistent with oceanic palaeontological data (Rögl, 1999; Harzhauser et al., 2007, 2009; Reuter et al., 2009). Our results are in disagreement with the study of Hüsing et al. (2009), who suggested that a connection between the Mediterranean Sea and the Indian Ocean still existed at $11 \mathrm{Ma}$.

The present study allows a better understanding of the impact of shoaling and closing the Tethys seaway, which can provide new constraints on the timing of this event. In particular, our results highlighted the existence of TISW in the deep-open experiments, and the absence of this water mass in the Mio250 and MioC experiments. Although the presence of TISW in the Indian Ocean between 17 and $5 \mathrm{Ma}$ is not unambiguously inferred from isotopic data (Smart et al., 2007), we suggest that TISW termination was closely linked to Tethys seaway shoaling and closure. New data providing a more precise and reliable record of TISW during the middle Miocene should therefore help to better constrain the timing of the Tethys seaway final closure.

\subsection{The cause of the Middle Miocene Climatic Transition}

Our results suggest that the eastern Tethys seaway closure was crucial for ocean dynamic changes but was not the major cause of the MMCT. Another factor should have initiated the Middle Miocene Climatic Transition, for example an atmospheric $\mathrm{CO}_{2}$ decrease or orbital parameter variations. This result is consistent with those of previous modelling studies on the respective roles of seaway closure or opening and atmospheric $\mathrm{CO}_{2}$ concentration in global climate change and polar glaciation (DeConto and Pollard, 2003; Huber and Nof, 2006; Lunt et al., 2008). Using ice-sheet modelling, DeConto and Pollard (2003) studied Antarctica ice-sheet growth during the Eocene-Oligocene transition (ca. $55 \mathrm{Ma}$ ). Their results demonstrated that the closure of the Drake Passage and subsequent increase in poleward heat transport has only a non-significant impact on Antarctica ice-sheet development. They also show that a decrease in atmospheric $\mathrm{CO}_{2}$ concentration is the most probable cause of this event (DeConto and Pollard, 2003). Moreover, Huber and Nof (2006) performed experiments with fixed sea-surface temperatures and demonstrated that large changes in Southern Ocean temperatures and oceanic heat transport have a nonsignificant impact on the Antarctic climate. Therefore it is accepted that an atmospheric $\mathrm{CO}_{2}$ concentration drawdown is the most probable cause of the global cooling and Antarctic ice-sheet development during the Eocene-Oligocene transition, and that the opening of the Drake Passage had only a non-significant impact on the Antarctic climate (DeConto 
and Pollard, 2003; Huber and Nof, 2006). This view is also supported by data-based palaeoceanographic reconstructions (Huber et al., 2004).

Lunt et al. (2008) also performed experiments using an ice-sheet model to study the development of the Greenland Ice Sheet during the Pliocene (approximately $3 \mathrm{Ma}$ ). As for the Antarctic ice-sheet growth, diverse hypotheses have been proposed for this glaciation: it was due either to a $p \mathrm{CO}_{2}$ drawdown or to the closure of the Panama gateway and subsequent oceanic changes. The results of the sensitivity experiments from Lunt et al. (2008) show that the closure of the gateway has little effect on the Greenland Ice Sheet, whereas atmospheric $\mathrm{CO}_{2}$ concentration is a critical factor for its building. These previous modelling studies highlighted the major role of $\mathrm{CO}_{2}$ in global climatic transitions, and also suggested that even dramatic changes in gateway configuration have only non-significant impacts on ice-sheet growth.

In the present study, we demonstrate that the closure of the eastern Tethys seaway during the middle Miocene largely impacted the global oceanic circulation but had little effect on the Antarctic climate. These results are consistent with those of DeConto and Pollard (2003) and Lunt et al. (2008), and suggest that another parameter, probably an atmospheric $\mathrm{CO}_{2}$ drawdown, should have initiated the Middle Miocene Climatic Transition. However, the oceanic changes induced by the Tethys seaway closure, in particular the intensification of the ACC, should have amplified the cooling and icesheet growth. Recently Bijl et al. (2013) argued that the regional cooling of the Southern Ocean during the EoceneOligocene transition was due to the opening of the Drake Passage, although the global cooling can better be explained by $p \mathrm{CO}_{2}$ decrease. In our experiments, we simulate strong regional cooling in the Indian Ocean, which is entirely due to the Tethys seaway closure. Therefore we can argue that tectonic changes can drive important regional climate changes, as is suggested in Bijl et al. (2013), but global climate change should involve other mechanisms.

Using the coupled model ECHAM5, Krapp and Jungclaus (2011) tested the impact of varying $p \mathrm{CO}_{2}$ on middle Miocene climate. Their results indicate a sensitivity to doubled $p \mathrm{CO}_{2}$ of $4.2^{\circ} \mathrm{C}$. Hamon et al. (2012) also studied the impact of $\mathrm{CO}_{2}$ concentration on middle Miocene climate using the coupled model FOAMv1.5, and found a sensitivity to doubled $p \mathrm{CO}_{2}$ of $4.6^{\circ} \mathrm{C}$. Interestingly, the IPCC report indicates a sensitivity to doubled $\mathrm{CO}_{2}$ concentration of $2.6^{\circ} \mathrm{C}$ for ECHAM5 with present-day configuration, which is $1.6^{\circ} \mathrm{C}$ lower than for the Miocene. We also performed a control experiment with doubled $p \mathrm{CO}_{2}\left(560^{\circ} \mathrm{C}\right.$ instead of $\left.280^{\circ} \mathrm{C}\right)$ with the model FOAM, and calculated a sensitivity of $1.5^{\circ} \mathrm{C}$, which is $3^{\circ} \mathrm{C}$ lower that for the Miocene configuration. This suggests that the sensitivity to atmospheric $\mathrm{CO}_{2}$ concentration was higher during the middle Miocene, which is due to the important changes in the oceanic circulation compared to the present day (Krapp and Jungclaus, 2011; Hamon et al., 2012). The closure of the Tethys seaway, by modifying the oceanic circulation, should therefore have an impact on climatic sensitivity to $\mathrm{CO}_{2}$ concentration. New simulations testing varying atmospheric $\mathrm{CO}_{2}$ concentrations with open and closed eastern Tethys are therefore needed to better understand the respective roles of $p \mathrm{CO}_{2}$ and eastern Tethys seaway on middle Miocene climate.

\section{Conclusions}

In this work we investigated the impact of varying eastern Tethys seaway configurations on middle Miocene oceanic circulation and climate. We performed four sensitivity experiments with various Tethys seaway depths $(4000,1000$, 250 and $0 \mathrm{~m}$ ). We highlighted the existence of warm and saline deep water in the Indian Ocean when the Tethys seaway is deep open (4000 or $1000 \mathrm{~m}$ ), which corresponds to the TISW described in studies based on isotopic composition of benthic foraminifera (Woodruff and Savin, 1989; Wright et al., 1992; Flower and Kennett, 1994, 1995; Ramsay et al., 1998). We demonstrated that the shoaling of the Tethys seaway to $250 \mathrm{~m}$ and ultimately its closure provoked the termination of TISW production, inducing important temperature and salinity changes in the Indian Ocean. This led to changes in the latitudinal density gradient and to the acceleration of the ACC. Moreover, when the Tethys seaway is closed or shallow, the warm and salty water from the protoMediterranean Basin is transported in the Atlantic Ocean through the Gibraltar Strait, enhancing the AMOC. These results are in good agreement with isotopic studies (Woodruff and Savin, 1989; Wright et al., 1992; Flower and Kennett, 1994, 1995; Kuhnert et al., 2009; Verducci et al., 2009), but differ from other modelling studies. New experiments with diverse ocean-atmosphere models and consistent model inter-comparison should be conducted in the future to better constrain the role of the Tethys seaway final closure in the middle Miocene oceanic circulation reorganisation.

Our results also bring new constraints on the Tethys seaway final closure. The presence of TISW in experiments with deep-open Tethys seaway, and its absence in the shallow experiment, indicate that during the MMCT, when the TISW production terminated, the eastern Tethys seaway was likely shallow. However, we cannot provide any information on the initial collision between Afro-Arabia and Eurasia, and further work is needed to bring new constraints on this event. More sensitivity experiments testing Tethys seaway depth between 250 and $1000 \mathrm{~m}$ should also provide important constraints on the timing of the final closure of the eastern Tethys seaway.

The climatic changes caused by the Tethys seaway closure do not appear sufficient to explain the rapid ice-sheet growth over Antarctica during the MMCT. Another mechanism should have initiated the global cooling and the oceanic changes induced by the Tethys seaway closure added to its effects. Many authors have proposed a $p \mathrm{CO}_{2}$ decrease as 
the main driver of the Middle Miocene Climatic Transition and cryospheric expansion in Antarctica (Kürschner et al., 2008; Kürschner and Kvacek, 2009; Tripati et al., 2009; Foster et al., 2012; Badger et al., 2013). The recently published sensitivity tests on Miocene $p \mathrm{CO}_{2}$ indicate that a drawdown of this gas concentration could have been key in the MMCT (Tong et al., 2009; You et al., 2009; Henrot et al., 2010; Krapp and Jungclaus, 2011; Hamon et al., 2012). The climate sensitivity to such a $\mathrm{CO}_{2}$ concentration drawdown was likely different from the present-day sensitivity, due to the oceanic changes induced by the Tethys seaway closure. However, the cause of this $p \mathrm{CO}_{2}$ decrease is not fully understood yet. Vincent and Berger (1985) proposed the so-called "Monterey hypothesis", according to which the burial of organic carbon during the middle Miocene induced a $p \mathrm{CO}_{2}$ shift and initiated the global cooling. This hypothesis is based on the positive excursion of $\delta^{13} \mathrm{C}$ and the presence of organic-rich deposits along the Pacific margins (Vincent and Berger, 1985). Moreover, in the same time the elevation of the high reliefs, such as the Andes, the Alps, the Himalayas and the Tibetan Plateau, should have enhanced silicate weathering, contributing to the $p \mathrm{CO}_{2}$ drawdown during the middle Miocene (Gregory-Wodzicki, 2000; Foeken et al., 2003; Currie et al., 2005; Garzione et al., 2006, 2008). Future studies should focus on the respective roles of $\mathrm{CO}_{2}$ concentration, orbital parameter and Tethys seaway closure in the MMCT. In particular, combining climate and carbon cycle modelling with $\delta^{13} \mathrm{C}$ analysis should allow a test of the Monterey hypothesis and improve our knowledge of the links between carbon cycle, climate and seaway closure during the Miocene.

Acknowledgements. We are particularly grateful to M. Brunet and the Collège de France, thanks to whom this work has been performed under the best circumstances. We also want to acknowledge P. Vignaud and the CNRS, as well as the CEA and Région PoitouCharentes for the funding of this study. This work was performed using HPC resources from GENCI [CCRT/TGCC/CINES/IDRIS] (grant 2013- [t2013012212]).

Edited by: A. Sluijs

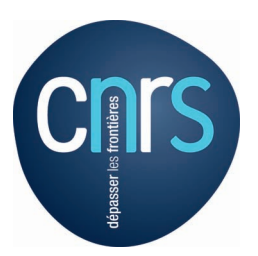

The publication of this article is financed by CNRS-INSU.

\section{References}

Allen, M. B. and Armstrong, H. A.: Arabia-Eurasia collision and the forcing of mid-Cenozoic global cooling, Palaeogeogr. Palaeocl., 265, 52-58, doi:10.1016/j.palaeo.2008.04.021, 2008.

Badger, M. P. S., Lear, C. H., Pancost, R. D., Foster, G. L., Bailey, T. R., Leng, M. J., and Abels, H. A.: $\mathrm{CO}_{2}$ drawdown following the middle Miocene expansion of the Antarctic Ice Sheet, Paleoceanography, 28, 42-53, doi:10.1002/palo.20015, 2013.

Bijl, P. K., Bendle, J. A. P., Bohaty, S. M., Pross, J., Schouten, S., Tauxe, L., Stickley, C. E., McKay, R. M., Röhl, U., Olney, M., Sluijs, A., Escutia, C., Brinkhuis, H., and Expedition 318 Scientists: Eocene cooling linked to early flow across the Tasmanian Gateway, P. Natl. Acad. Sci. USA, 110, 9645-9650, doi:10.1073/pnas.1220872110, 2013

Billups, K. and Schrag, D.: Paleotemperatures and ice volume of the past $27 \mathrm{Myr}$ revisited with paired $\mathrm{Mg} / \mathrm{Ca}$ and ${ }^{18} \mathrm{O} /{ }^{16} \mathrm{O}$ measurements on benthic foraminifera, Paleoceanography, 17, 1003, doi:10.1029/2000PA000567, 2002.

Bruch, A. A., Uhl, D., and Mosbrugger, V.: Miocene climate in Europepatterns and evolution: a first synthesis of NECLIME, Palaeogeogr. Palaeocl., 253, 1-7, doi:10.1016/j.palaeo.2007.03.030, 2007.

Butzin, M., Lohmann, G., and Bickert, T.: Miocene ocean circulation inferred from marine carbon cycle modeling combined with benthic isotope records, Paleoceanography, 26, PA1203, doi:10.1029/2009PA001901, 2011.

Cerling, T. E.: Carbon dioxide in the atmosphere: evidence from Cenozoic and Mesozoic paleosols, Am. J. Sci., 291, 377-400, doi:10.2475/ajs.291.4.377, 1991.

Chaboureau, A.-C., Donnadieu, Y., Sepulchre, P., Robin, C., Guillocheau, F., and Rohais, S.: The Aptian evaporites of the South Atlantic: a climatic paradox?, Clim. Past, 8, 1047-1058, doi:10.5194/cp-8-1047-2012, 2012.

Currie, B. S., Rowley, D. B., and Tabor, N. J.: Middle Miocene paleoaltimetry of southern Tibet: implications for the role of mantle thickening and delamination in the Himalayan orogen, Geology, 33, 181-184, doi:10.1130/G21170.1, 2005.

DeConto, R. M. and Pollard, D.: Rapid Cenozoic glaciation of Antarctica induced by declining atmospheric $\mathrm{CO}_{2}$, Nature, 421, 245-249, doi:10.1038/nature01290, 2003.

DeConto, R. M., Pollard, D., and Harwood, D.: Sea ice feedback and Cenozoic evolution of Antarctic climate and ice sheets, $\mathrm{Pa}-$ leoceanography, 22, 1-18, doi:10.1029/2006PA001350, 2007.

Donnadieu, Y., Pierrehumbert, R., Jacob, R., and Fluteau, F.: Modelling the primary control of paleogeography on Cretaceous climate, Earth Planet. Sc. Lett., 248, 426-437, doi:10.1016/j.eps1.2006.06.007, 2006.

Flower, B. P. and Kennett, J. P.: The middle Miocene climatic transition: East Antarctic ice sheet development, deep ocean circulation and global carbon cycling, Palaeogeogr. Palaeocl., 108, 537555, doi:10.1016/0031-0182(94)90251-8, 1994.

Flower, B. P. and Kennett, J. P.: Middle Miocene deepwater paleoceanography in the southwest Pacific: relations with East Antarctic Ice Sheet development, Paleoceanography, 10, 1095-1112, doi:10.1029/95PA02022, 1995.

Foeken, J., Dunai, T., Bertotti, G., and Andriessen, P.: Late Miocene to present exhumation in the Ligurian Alps (southwest Alps) with evidence for accelerated denudation during the Messinian salinity crisis, Geology, 31, 797-800, doi:10.1130/G19572.1, 2003. 
Foster, G. L., Lear, C. H., and Rae, J. W. B.: The evolution of $p \mathrm{CO}_{2}$, ice volume and climate during the middle Miocene, Earth Planet. Sc. Lett., 341-344, 243-254, doi:10.1016/j.eps1.2012.06.007, 2012.

Garzione, C. N., Molnar, P., Libarkin, J. C., and MacFadden, B. J.: Rapid late Miocene rise of the Bolivian Altiplano: Evidence for removal of mantle lithosphere, Earth Planet. Sc. Lett., 241, 543556, doi:10.1016/j.epsl.2005.11.026, 2006.

Garzione, C. N., Hoke, G. D., Libarkin, J. C., Withers, S., MacFadden, B., Eiler, J., Ghosh, P., and Mulch, A.: Rise of the Andes, Science, 320, 1304-1307, doi:10.1126/science.1148615, 2008.

Gregory-Wodzicki, K. M.: Uplift history of the Central and Northern Andes: a review, Geol. Soc. Am. Bull., 112, 1091-1105, doi:10.1130/0016-7606(2000)112<1091:UHOTCA>2.0.CO;2, 2000.

Hamon, N., Sepulchre, P., Donnadieu, Y., Henrot, A.-J., François, L., Jaeger, J.-J., and Ramstein, G.: Growth of subtropical forests in Miocene Europe: The roles of carbon dioxide and Antarctic ice volume, Geology, 40, 567-570, doi:10.1130/G32990.1, 2012.

Harzhauser, M. and Piller, W. E.: Benchmark data of a changing seapalaeogeography, palaeobiogeography and events in the Central Paratethys during the Miocene, Palaeogeogr. Palaeocl., 253, 8-31, doi:10.1016/j.palaeo.2007.03.031, 2007.

Harzhauser, M., Kroh, A., Mandic, O., Piller, W. E., Göhlich, U., Reuter, M., and Berning, B.: Biogeographic responses to geodynamics: a key study all around the Oligo-Miocene Tethyan Seaway, Zool. Anz., 246, 241-256, doi:10.1016/j.jcz.2007.05.001, 2007.

Harzhauser, M., Reuter, M., Piller, W. E., Berning, B., Kroh, A., and Mandic, O.: Oligocene and Early Miocene gastropods from Kutch (NW India) document an early biogeographic switch from Western Tethys to Indo-Pacific, Palaeont. Z., 83, 333-372, doi:10.1007/s12542-009-0025-5, 2009.

Henrot, A.-J., François, L., Favre, E., Butzin, M., Ouberdous, M., and Munhoven, G.: Effects of $\mathrm{CO}_{2}$, continental distribution, topography and vegetation changes on the climate at the Middle Miocene: a model study, Clim. Past, 6, 675-694, doi:10.5194/cp6-675-2010, 2010.

Herold, N., Seton, M., Müller, R., You, Y., and Huber, M.: Middle Miocene tectonic boundary conditions for use in climate models, Geochem. Geophy. Geosy., 9, Q10009, doi:10.1029/2008GC002046, 2008.

Herold, N., You, Y., Müller, R., and Seton, M.: Climate model sensitivity to changes in Miocene paleotopography, Aust. J. Earth. Sci., 56, 1049-1059, doi:10.1080/08120090903246170, 2009.

Herold, N., Huber, M., Greenwood, D., Müller, R., and Seton, M.: Early to Middle Miocene monsoon climate in Australia, Geology, 39, 3-6, doi:10.1130/G31208.1, 2011.

Herold, N., Huber, M., Müller, R., and Seton, M.: Modeling the Miocene climatic optimum: Ocean circulation, Paleoceanography, 27, PA1209, doi:10.1029/2010PA002041, 2012.

Holbourn, A., Kuhnt, W., Schulz, M., and Erlenkeuser, H.: Impacts of orbital forcing and atmospheric carbon dioxide on Miocene ice-sheet expansion, Nature, 438, 483-487, doi:10.1038/nature04123, 2005.

Holbourn, A., Kuhnt, W., Frank, M., and Haley, B. A.: Changes in Pacific Ocean circulation following the Miocene onset of permanent Antarctic ice cover, Earth Planet. Sc. Lett., 365, 38-50, doi:10.1016/j.eps1.2013.01.020, 2013.
Huber, M. and Nof, D.: The ocean circulation in the southern hemisphere and its climatic impacts in the Eocene, Palaeogeogr. Palaeocl., 231, 9-28, doi:10.1016/j.palaeo.2005.07.037, 2006.

Huber, M., Brinkhuis, H., Stickley, C. E., Döös, K., Sluijs, A., Warnaar, J., Schellenberg, S. A., and Williams, G. L.: Eocene circulation of the Southern Ocean: Was Antarctica kept warm by subtropical waters?, Paleoceanography, 19, doi:10.1029/2004PA001014, 2004.

Hüsing, S. K., Zachariasse, W.-J., van Hinsbergen, D. J., Krijgsman, W., Inceöz, M., Harzhauser, M., Mandic, O., and Kroh, A.: Oligocene-Miocene basin evolution in SE Anatolia, Turkey: constraints on the closure of the eastern Tethys gateway, Geological Society, London, Special Publications, 311, 107-132, doi:10.1144/SP311.4, 2009.

Ivanovic, R. F., Valdes, P. J., Gregoire, L., Flecker, R., and Gutjahr, M.: Sensitivity of modern climate to the presence, strength and salinity of Mediterranean-Atlantic exchange in a global general circulation model, Clim. Dynam., 1-19, doi:10.1007/s00382013-1680-5, 2013.

Jacob, R. L.: Low frequency variability in a simulated atmosphere ocean system, Ph.D. thesis, University of Wisconsin, 1997.

Karami, M., Meijer, P. T., Dijkstra, H., and Wortel, M.: An oceanic box model of the Miocene Mediterranean Sea with emphasis on the effects of closure of the eastern gateway, Paleoceanography, 24, PA4203 , doi:10.1029/2008PA001679, 2009.

Karami, M., De Leeuw, A., Krijgsman, W., Meijer, P. T., and Wortel, M.: The role of gateways in the evolution of temperature and salinity of semi-enclosed basins: An oceanic box model for the Miocene Mediterranean Sea and Paratethys, Global Planet. Change, 79, 73-88, doi:10.1016/j.gloplacha.2011.07.011, 2011.

Krapp, M. and Jungclaus, J. H.: The Middle Miocene climate as modelled in an atmosphere-ocean-biosphere model, Clim. Past, 7, 1169-1188, doi:10.5194/cp-7-1169-2011, 2011.

Kuhnert, H., Bickert, T., and Paulsen, H.: Southern Ocean frontal system changes precede Antarctic ice sheet growth during the middle Miocene, Earth Planet. Sc. Lett., 284, 630-638, doi:10.1016/j.eps1.2009.05.030, 2009.

Kürschner, W. M. and Kvacek, Z.: Oligocene-Miocene $\mathrm{CO}_{2}$ fluctuations, climatic and palaeofloristic trends inferred from fossil plant assemblages in central Europe, B. Geosci., 84, 189-202, doi:10.3140/bull.geosci.1091, 2009.

Kürschner, W. M., Kvaček, Z., and Dilcher, D. L.: The impact of Miocene atmospheric carbon dioxide fluctuations on climate and the evolution of terrestrial ecosystems, P. Natl. Acad. Sci., 105, 449-453, doi:10.1073/pnas.0708588105, 2008.

Lefebvre, V., Donnadieu, Y., Sepulchre, P., Swingedouw, D., and Zhang, Z.-S.: Deciphering the role of southern gateways and carbon dioxide on the onset of the Antarctic Circumpolar Current, Paleoceanography, 27, PA4201, doi:10.1029/2012PA002345, 2012.

Lunt, D. J., Foster, G. L., Haywood, A. M., and Stone, E. J.: Late Pliocene Greenland glaciation controlled by a decline in atmospheric $\mathrm{CO}_{2}$ levels, Nature, 454, 1102-1105, doi:10.1038/nature07223, 2008.

Mosbrugger, V., Utescher, T., and Dilcher, D. L.: Cenozoic continental climatic evolution of Central Europe, P. Natl. Acad. Sci USA, 102, 14964-14969, doi:10.1073/pnas.0505267102, 2005. 
Okay, A. I., Zattin, M., and Cavazza, W.: Apatite fission-track data for the Miocene Arabia-Eurasia collision, Geology, 38, 35-38, doi:10.1130/G30234.1, 2010.

Pagani, M., Arthur, M. A., and Freeman, K. H.: Miocene evolution of atmospheric carbon dioxide, Paleoceanography, 14, 273-292, doi:10.1029/1999PA900006, 1999.

Pagani, M., Caldeira, K., Berner, R., and Beerling, D. J.: The role of terrestrial plants in limiting atmospheric $\mathrm{CO}_{2}$ decline over the past 24 million years, Nature, 460, 85-88, doi:10.1038/nature08133, 2009.

Pearson, P. N. and Palmer, M. R.: Atmospheric carbon dioxide concentrations over the past 60 million years, Nature, 406, 695-699, doi:10.1038/35021000, 2000.

Poulsen, C. J., Pierrehumbert, R. T., and Jacob, R. L.: Impact of ocean dynamics on the simulation of the Neoproterozoic" snowball Earth", Geophys. Res. Lett., 28, 1575-1578, doi:10.1029/2000GL012058, 2001.

Ramsay, A. T., Smart, C. W., and Zachos, J. C.: A model of early to middle Miocene deep ocean circulation for the Atlantic and Indian Oceans, Geological Society, London, Special Publications, 131, 55-70, doi:10.1144/GSL.SP.1998.131.01.04, 1998.

Reuter, M., Piller, W., Harzhauser, M., Mandic, O., Berning, B., Rögl, F., Kroh, A., Aubry, M.-P., Wielandt-Schuster, U., and Hamedani, A.: The Oligo-/Miocene Qom Formation (Iran): evidence for an early Burdigalian restriction of the Tethyan Seaway and closure of its Iranian gateways, Int. J. Earth Sci., 98, 627650, doi:10.1007/s00531-007-0269-9, 2009.

Rögl, F.: Mediterranean and Paratethys. Facts and hypotheses of an Oligocene to Miocene paleogeography (short overview), Geologica carpathica, 50, 339-349, 1999.

Royer, D. L., Wing, S. L., Beerling, D. J., Jolley, D. W., Koch, P. L., Hickey, L. J., and Berner, R. A.: Paleobotanical evidence for near present-day levels of atmospheric $\mathrm{CO}_{2}$ during part of the Tertiary, Science, 292, 2310-2313, doi:10.1126/science.292.5525.2310, 2001.

Shevenell, A. E., Kennett, J. P., and Lea, D. W.: Middle Miocene southern ocean cooling and Antarctic cryosphere expansion, Science, 305, 1766-1770, doi:10.1126/science.1100061, 2004.

Shevenell, A. E., Kennett, J. P., and Lea, D. W.: Middle Miocene ice sheet dynamics, deep-sea temperatures, and carbon cycling: A Southern Ocean perspective, Geochem. Geophy. Geosy., 9, Q02006, doi:10.1029/2007GC001736, 2008.

Smart, C. W., Thomas, E., and Ramsay, A. T.: Middle-late Miocene benthic foraminifera in a western equatorial Indian Ocean depth transect: Paleoceanographic implications, Palaeogeogr. Palaeocl., 247, 402-420, doi:10.1016/j.palaeo.2006.11.003, 2007.

Tobis, M., Schafer, C., Foster, I., Jacob, R., and Anderson, J.: FOAM: Expanding the horizons of climate modeling, in: Supercomputing, ACM/IEEE 1997 Conference, 27-27, IEEE, doi:10.1145/509593.509620, 1997.

Tong, J., You, Y., Müller, R., and Seton, M.: Climate model sensitivity to atmospheric $\mathrm{CO}_{2}$ concentrations for the middle Miocene, Global Planet. Change, 67, 129-140, doi:10.1016/j.gloplacha.2009.02.001, 2009.
Tripati, A. K., Roberts, C. D., and Eagle, R. A.: Coupling of $\mathrm{CO}_{2}$ and ice sheet stability over major climate transitions of the last 20 million years, Science, 326, 1394-1397, doi:10.1126/science.1178296, 2009.

Utescher, T., Bruch, A. A., Micheels, A., Mosbrugger, V., and Popova, S.: Cenozoic climate gradients in Eurasiaa palaeoperspective on future climate change?, Palaeogeogr. Palaeocl., 304, 351-358, doi:10.1016/j.palaeo.2010.09.031, 2011.

Verducci, M., Foresi, L., Scott, G., Sprovieri, M., Lirer, F., and Pelosi, N.: The Middle Miocene climatic transition in the Southern Ocean: Evidence of paleoclimatic and hydrographic changes at Kerguelen plateau from planktonic foraminifers and stable isotopes, Palaeogeogr. Palaeocl., 280, 371-386, doi:10.1016/j.palaeo.2009.06.024, 2009.

Vincent, E. and Berger, W. H.: Carbon dioxide and polar cooling in the Miocene: The Monterey hypothesis, in: The Carbon Cycle and Atmospheric CO: Natural Variations Archean to Present, edited by: Sundquist, E. T. and Broecker, W. S., American Geophysical Union, Washington D.C., 455-468, doi:10.1029/GM032p0455, 1985.

von der Heydt, A. and Dijkstra, H. A.: Flow reorganizations in the Panama Seaway: A cause for the demise of Miocene corals?, Geophys. Res. Lett., 32, L02609, doi:10.1029/2004GL020990, 2005.

von der Heydt, A. and Dijkstra, H. A.: Effect of ocean gateways on the global ocean circulation in the late Oligocene and early Miocene, Paleoceanography, 21, PA1011, doi:10.1029/2005PA001149, 2006.

Wolfe, J.: Distribution of major vegetational types during the Tertiary, in: The Carbon Cycle and Atmospheric $\mathrm{CO}_{2}$ : Natural variations, Archaean to Present, edited by: Sundquist, E. and Broecker, W., 357-375, American Geophysical Union Monograph, 32, doi:10.1029/GM032p0357, 1985.

Woodruff, F. and Savin, S. M.: Miocene deepwater oceanography, Paleoceanography, 4, 87-140, doi:10.1029/PA004i001p00087, 1989.

Wright, J. D., Miller, K. G., and Fairbanks, R. G.: Early and middle Miocene stable isotopes: implications for deepwater circulation and climate, Paleoceanography, 7, 357-389, doi:10.1029/92PA00760, 1992.

You, Y., Huber, M., Müller, R., Poulsen, C., and Ribbe, J.: Simulation of the middle Miocene climate optimum, Geophys. Res. Lett., 36, L04702, doi:10.1029/2008GL036571, 2009.

Zachos, J., Pagani, M., Sloan, L., Thomas, E., and Billups, K.: Trends, rhythms, and aberrations in global climate $65 \mathrm{Ma}$ to present, Science, 292, 686-693, doi:10.1126/science.1059412, 2001.

Zhang, Z., Nisancioglu, K. H., Flatøy, F., Bentsen, M., Bethke, I., and Wang, H.: Tropical seaways played a more important role than high latitude seaways in Cenozoic cooling, Clim. Past, 7, 801-813, doi:10.5194/cp-7-801-2011, 2011. 